\title{
STUDIES ON THE HELMINTH \\ FAUNA OF JAPAN -PART 53. \\ TREMATODES OF FISHES, XII-
}

$\operatorname{AUTHOR}(S)$ :

Yamaguti, Satyu

\section{CITATION:}

Yamaguti, Satyu. STUDIES ON THE HELMINTH FAUNA OF JAPAN -PART 53. TREMATODES OF FISHES, XII-. PUBLICATIONS OF THE SETO MARINE BIOLOGICAL LABORATORY 1958, 7(1): 53-88

\section{ISSUE DATE:}

1958-12-20

URL:

http://hdl.handle.net/2433/174599

RIGHT: 


\title{
STUDIES ON THE HELMINTH FAUNA OF JAPAN
}

\section{PAR'T 53. TREMATODES OF FISHES, XII}

\author{
SATYU YAMAGUTI \\ Department of Parasitology, Okayama University \\ Medical School, Okayama
}

With Plates III-IV

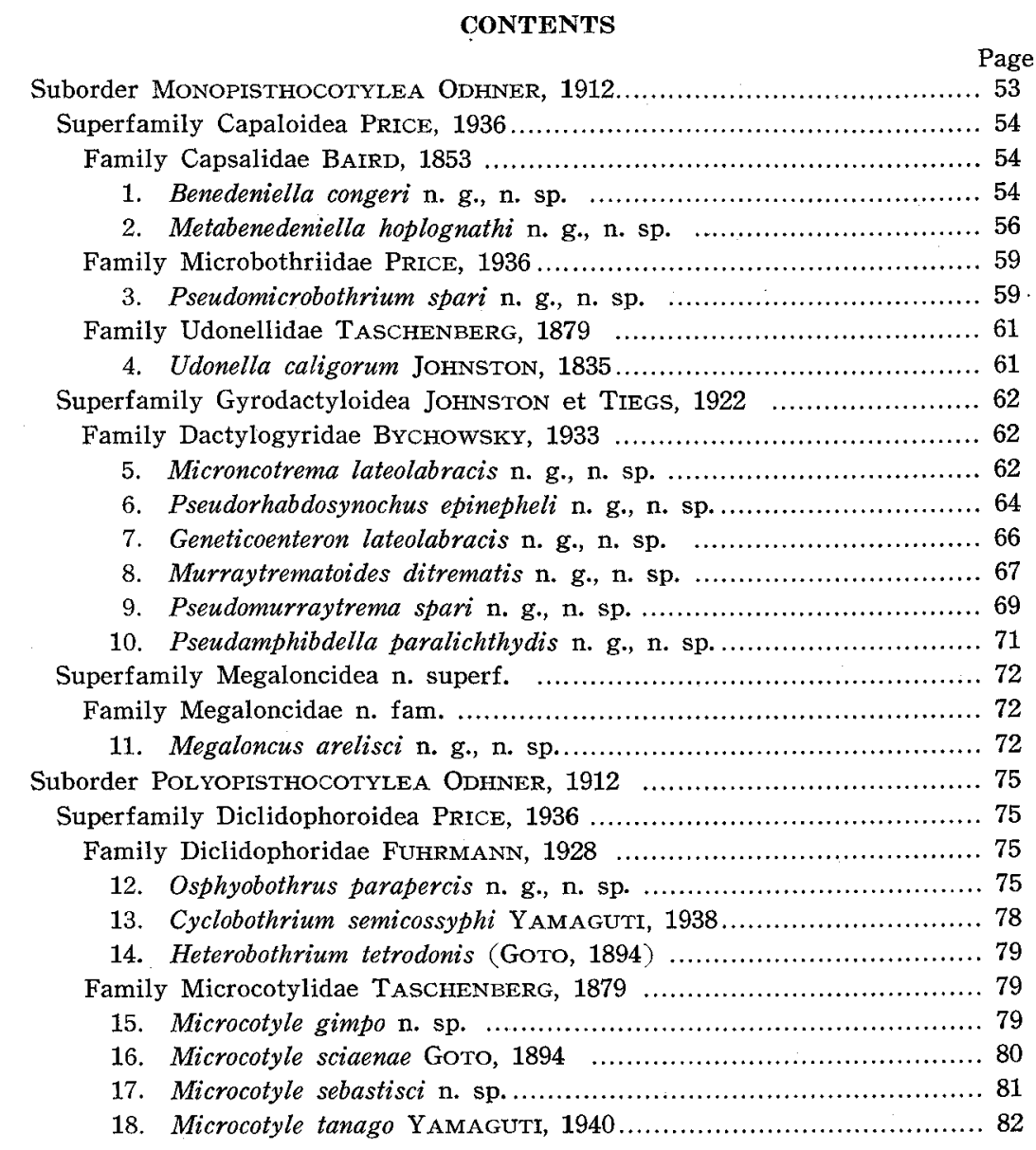

Publ. Seto Mar. Biol. Lab., VII (1), 1958. (Article 3) 
19. Prosomicrocotyla gotoi (YAMAGUTI, 1934) n. comb. ............. 83

20. Axine (Axinoides) sebastisci n. sp. ............................... 84

Superfamily PoLystomatoIdeA PRICE, 1936.................................... 85

Family Hexabothriidae PRICE, 1942 ....................................... 85

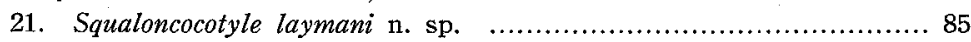

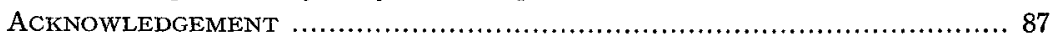

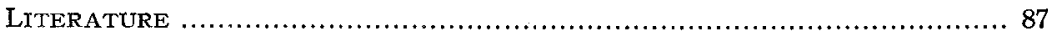

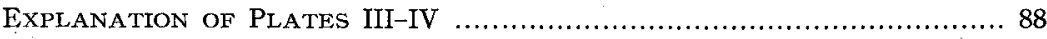

\section{MONOPISTHOCOTYLEA OdHNER, 1912}

Capsaloidea PRICE, 1936

Capsalidae BAIRD, 1853

1. Benedeniella congeri n. g., n. sp.

(PI. III, Fig. 4)

Habitat: Gills of Conger myriaster BREVOORT.

Material: A single mature specimen.

Locality and date: Inland Sea; September 11, 1957.

Body, including opisthohaptor, measuring $1.2 \mathrm{~mm}$ in length, with maximum width of $0.46 \mathrm{~mm}$ at about middle of body proper which is nearly elliptical in outline. Prohaptor prominent, sucker-like, with circular pit at center, oval in outline, $0.14 \times$ $0.15 \mathrm{~mm}$, connected with each other by concave membrane anterodorsally and separated ventrally by a distance of $80 \mu$. Opisthohaptor circular, about $0.35 \mathrm{~mm}$ anteroposteriorly, with narrow, frilled, marginal membrane, a number of marginal hooklets $8 \mu$ long, and three pairs of anchors; anterior anchor rod-shaped, $85 \mu$ long by $15 \mu$ wide, blunt-pointed at its free anterior end and terminating in two unequal tips; middle and posterior anchors slender, with ventrally curved sharp point, former $85 \mu$ long, latter about $39 \mu$ long. The anterior circular muscle fibers are converged toward the base of the middle anchor; radial muscles are well developed around the center, where the haptor is attached to the body proper; the oblique muscle bundles arising from the lateral portions of the body proper cross one another soon after entering the haptor and are split into individual fibers as they approach the anterior anchor; the bases of the anterior anchors are connected by transverse muscle bands, of which the anteriormost is the strongest; dorsoventral muscle bundles are well developed throughout the haptor except for the central and marginal areas.

Mouth oval, opening immediately behind two pairs of eye-spots; pharynx $0.1 \times$ $0.14 \mathrm{~mm}$, with a notch on each side and posterodorsally. Ceca with numerous, simple or branched, outer branches, terminating close to each other near posterior extremity of body proper; anteriormost branches approaching each other immediately in front of eye-spots.

Testes oval, pressed one against the other, just postequatorial, $0.25 \times 0.15 \mathrm{~mm}$. 
The vas deferens forming a transverse loop between the proximal transverse portion of the germiduct and the seminal receptacle passes along the left side of the seminal receptacle and after crossing the proximal end of the vagina dorsally runs forward and then turning to the right across the dorsal side of the ootype forms another loop dorsal to the prostatic reservoir before leading into the seminal vesicle enclosed in the cirrus pouch. The cirrus pouch, approximately claviform and $0.18 \mathrm{~mm}$ long, has a thick wall of circular muscle fibers and a maximum width of $62 \mu$ at the level of the swollen internal seminal vesicle. It contains a fusiform seminal vesicle continued into the narrow ejaculatory duct lined with thick smooth cuticle, and a club-shaped prostatic bulb provided with a thick wall of diagonal muscle fibers. The latter bulb is $0.17 \mathrm{~mm}$ long by $36 \mu$ wide and contains a column of spermatozoa in the center, and has a clear space between this column and its inner wall apparently devoid of epithial lining. Prostatic reservoir oval, $65 \mu$ long by $46 \mu$ wide, completely filled with spermatozoa instead of the prostatic secretion, which appears to be confined to the conical distal end of the reservoir, surrounding the central column of spermatozoa; the prostatic cells lie on the right of the reservoir, partly scattered among the vitelline cells, with their ducts converged toward the base of the reservoir. The cirrus pouch and the prostatic reservoir are enclosed in a thin-walled sac, which functions as genital atrium as it joins the uterus. The distal end of the ejaculatory duct projects into the slightly dilated prostatic duct near the distal end of the cirrus pouch and then opens at the tip of the cirrus pouch into the genital atrium which in turn immediately opens outside ventrally close to the body margin behind the left haptoral sucker.

Ovary ovoid, $0.1 \times 0.11 \mathrm{~mm}$, situated medianly immediately in front of two testes; the germiduct running from the left to the right along the anterior border of the ovary joins the seminal duct coming obliquely backward from the seminal receptacle, and turning back on itself anterodextral to the ovary leads into the uterus. The narrow proximal portion of the uterus lined with epithelia is tubular and surrounded by shell gland cells. The uterus proper is ovoid, $52 \mu$ by $36 \mu$, and opens into the genital atrium by a very short narrow duct lined with cuticle. The whole uterus is enclosed in a subcylindrical membranous sac, which in turn is sourrounded by a dense coat of glandular cells except at the two extremities. No eggs observed. Vagina well chitinized, subcylindrical, $26 \mu$ long by $14 \mu$ wide, opening slightly dorsally on left margin of body at level of pharynx; vaginal duct long and simple for greater distal portion but twisted proximally; seminal receptacle $39 \times 31 \mu$, filled with spermatozoa, situated anterosinistral to ovary, seminal duct about $30 \mu$ long by $7.5 \mu$ wide. Vitellaria surrounding whole intestine and its branches, confluent across median line in front of eye-spots as well as in posttesticular area. Paired excretory vesicles opening dorsally at level of prostatic reservoir.

The present genus is distinguished from the related known genera of Benedeniinae in the cirrus pouch containing the seminal vesicle and a strongly differentiated prostatic duct, and being enclosed in toto in the genital atrium. Further, the presence 
of a seminal receptacle filled with spermatozoa in place of the vitelline reservoir and that the whole uterus is enclosed in a membranous sac are worth noting.

\section{Benedeniella n. g.}

Generic diagnosis.-Capsalidae, Benedeniinae: Oculate. Prohaptor sucker-like, not enclosed in membranous hood. Opisthohaptor with marginal hooklets and marginal membrane; of the three pairs of anchors the anterior is wedge-shaped and bifid at the posterior end, each of the middle and posterior pairs has a sharp recurved point. Pharynx indented, ceca with outer branches, not united posteriorly. Testes juxtaposed. Vas deferens strongly winding, seminal vesicle en. closed in cirrus pouch along with strongly muscular prostatic bulb; ductus ejaculatorius joining distal end of prostatic bulb and opening into genital atrium. Cirrus pouch and prostatic reservoir enclosed in a thin-walled sac, into which the uterus opens from behind near the base of the cirrus pouch. Genital pore opening ventrosubmarginally immediately behind left prohaptor. Ovary median, pretesticular. Uterus enclosed in membranous sac which is surrounded by gland cells. Eggs? Vagina subcylindrical, well chitinized, opening dorsomarginally well apart from genital pore. Vitellaria co-extensive with intestine and its branches, confluent anterior to eyespots and posterior to testes; vitelline reservoir? Parasitic on gills of marine teleosts.

Genotype: B. congeri n. sp.

\section{Metabenedeniella hoplognathi n. g., n. sp.}

(P1. III, Fig. 5)

Habitat: Gill of Hoplognathus fasciata and Epinephelus septemfasciatus.

Material : 22 mature specimens from first type host and two more from second host, fixed under cover glass pressure, stained and mounted in toto.

Locality and date: Suma Municipal Aquarium; April 9, 1958.

Body $1.5-2.2 \mathrm{~mm}$ in length inclusive of opisthohaptor, $0.75-1.05 \mathrm{~mm}$ in maximum breadth about middle of body proper, which is almost elliptical in outline. Prohaptor prominent, shaped like an oval saucer, $0.25-0.36 \times 0.17-0.23 \mathrm{~mm}$, with membranous border glandular in structure, showing dark-staining granules which are condensed in the equatorial zone, diminishing toward the anterior margin. The posterior part of the haptor devoid of dark granules is provided with fine muscle fibers which are perpendicular to the surface. The paired prohaptors are separated ventrally in the type $2.2 \mathrm{~mm}$ long by a distance of $26 \mu$; they are connected anterodorsally by a plane or concave membrane, and there is no overhanging hood-like formation.

Opisthohaptor circular, $0.6-0.75 \mathrm{~mm}$ in diameter including the marginal membrane, well provided with dorsoventral, radial and circular muscle fibers, of which some of the central radial fibers appear to be continued into the powerful longitudinal muscle bundles of the body proper. The marginal membrane divided into large numbers of lobes whose free outer margin is broadly rounded and may or may not be subdivided into three to five lobules. No marginal hooklets have been detected in contrast with Benedeniella. The three pairs of anchors are similar to those of Benedeniella congeri described above, measuring $93-120 \mu, 65-83 \mu$ and $60-86 \mu$ in respective length.

Two pairs of eye spots situated anterodorsal to pharynx. Mouth oval, opening 
between eye spots of posterior pair. Pharynx $0.140 .19 \times 0.15-0.27 \mathrm{~mm}$, with a distinct notch on each side. Esophagus practically absent ; ceca transverse at very beginning, with a dense, transversely elongated mass of pharyngeal gland cells immediately behind; their first two branches are directed forward and encircling the pharynx approach each other in the median line anterior to the eye spots; after giving off a few short inner branches and a number of terminally bifurcate outer branches almost reaching the lateral edge of the body, the ceca terminate at the level of the anterior end of the opisthohaptor.

Testes oval, juxtaposed at junction of middle with posterior third of body proper with their long axes widely divergent, occupying whole intercecal width, $0.12-0.3 \times$ $0.09-022 \mathrm{~mm}$. The vas deferens ascending along the sinistrodorsal side of the ovary turns to the right and after crossing the seminal receptacle dorsally turns back on itself to proceed in a serpentine course on the left of the uterus and then across it dorsally; finally it runs backward dorsal to the cirrus pouch, at the posterior end of which it turns back on itself to be continued into the ejaculatory duct. All the way through there is no dilatation of the duct in form of a seminal vesicle. The tubular cirrus pouch is $0.9-1.2 \mathrm{~mm}$ long and $0.04-0.07 \mathrm{~mm}$ wide at its somewhat swollen base, and follows a long serpentine course from the left marginal genital pore, past behind the intestinal bifurcation and medial to the right cecum, to the interspace between the ovary and the testes, and is enclosed throughout together with the prostatic bulb and the prostatic reservoir in a thin-walled capsule of longitudinal muscle, the distal portion of which, after it has joined the uterus, functions as a genital atrium as in Benedeniella congeri. Its wall consists of longitudinal muscle fibers in the distal portion down to the point where it turns backward to take the descending course from the postbifurcal transverse course, but to the remaining proximal portion is added a conspicuous outer layer of circular fibers, which increases in thickness as it proceeds backward. The ejaculałory duct, lined with thick cuticle and surrounded by circular muscle fibers, runs forward in the cirrus pouch along with the prostatic duct, but joins the latter probably near the point where the outer circular muscle layer of the cirrus pouch disappears; at this point of junction the outer circular muscle coat of the ejaculatory duct also disappears and the duct gives way to a long slender cirrus, which when everted, may attain a length of $0.27 \mathrm{~mm}$, and may be thust into either the genital atrium or the vaginal pore. A bean-shaped prostatic reservoir, $0.12-0.23 \times 0.06-0.11 \mathrm{~mm}$, and filled with fine prostatic granules, lies between the ovary and the left cecum, with its long axis parallel or somewhat oblique to that of the body; from its wider end arises a narrow duct which opens into the prostatic bulb by way of a small sphincter-like muscular swelling (20 $\mu$ in diameter in the type). The prostatic bulb containing a central column of prostatic secretion, is nearly fusiform, $0.12-0.2 \mathrm{~mm}$ long by $0.065-0.08 \mathrm{~mm}$ wide and lies obliquely between the ovary and the left testis, with its tapering distal end thrust into the base of the cirrus pouch and continued into the prostatic duct enclosed in the cirrus pouch; its extremely thick wall consists exclusively of fine oblique muscle fibers. Both the 
prostatic reservoir and the prostatic bulb are enclosed in the expanded basal portion of the capsule containing the cirrus pouch. The prostatic duct containing a continuous string of prostatic secretion is uniformly narrow; its thin wall consists of longitudinal muscle fibers alone. The genital atrium opens ventrally close to the anterolateral margin of the body beneath the left prohaptor.

Ovary rounded, $0.13-0.2 \mathrm{~mm}$ in diameter, situated in middle third of body proper, a little to right of median line. The germiduct, arising from the dorsal side of the ovary, first joins the duct coming from the vitelline reservoir and turns forward immediately anterodextral to the ovary and receives the narrow duct from the seminal receptacle. The ootype and the somewhat winding uterine duct are surrounded by shell gland cells which extend profusely in the area between the cirrus pouch and the vagina. In the expanded uterus proper lined with conspicuous epithelia is found in one specimen or two a single brown oval egg $91-104 \mu$ in diameter and provided at one pole with a recurved process about $85 \mu$ long. The uterus proper opens into the genital atrium posterolateral to the pharynx just behind the intestinal bifurcation. Vitellaria co-extensive with intestine and its branches, confluent in front of eye-spot as well as in posttesticular area; vitelline reservoir $0.05-0.14 \mathrm{~mm}$ anteroposteriorly, situated transversely immediately in front of ovary, receiving a collecting vitelline duct at each outer end; the vitelline duct joining the germiduct is given off from the dorsal side of the vitelline reservoir. Vagina tubular, $0.36-0.55 \mathrm{~mm}$ long by $0.03-0.05 \mathrm{~mm}$ wide, lined with cuticle and provided with muscular coat of inner longitudinal and outer circular fibers, running obliquely forward across left cecum dorsally and opening slightly dorsally on left margin of body at level of pharynx. Seminal receptacle spherical, $30-60 \mu$ in diameter, immediately in front of vitelline reservoir, connected with vagina by a short, narrow, somewhat winding duct, and with the germiduct by a straight narrow duct.

This genus differs from the most closely related Benedeniella essentially in the cirrus pouch being extremely long and extending into the space between the ovary and the right testis, in the cirrus being very long and eversible, in the prostatic bulb lying outside tte cirrus pouch between the ovary and the left testis, and in the prostatic reservoir being shifted to the left of the ovary. The prohaptors are suckerlike in Benedeniella, but saucer-like and more glandular in the present genus. That the vitelline reservoir is well developed in the front of the ovary, that the uterus is not enclosed in a membranous sac and that the vagina proper is a very long muscular organ in connection with the long eversible cirrus are also important characters differentiating the present genus from Benedeniella.

Metabenedeniella n. g.

Generic diagnosis. - Capsalidae, Benedeniinae: Oculate. Prohaptor saucer-like, glandular. Opisthohaptor with festooned or frilled marginal membrane, without marginal hooklets; of the three pairs of anchors the anterior is wedge-shaped and bifid at the posterior end while the other pairs are hook-shaped. Pharynx indented, with pharyngeal gland cells behind intestinal 
bifurcation. Ceca with numerous, $\mathrm{Y}$-shaped, side branches, not united posteriorly. Testes juxtaposed, postequatorial. Vas deferens winding forward, and then backward dorsal to cirrus pouch, at the base of which it passes into the ejaculatory duct. Latter well provided outside with circular muscle fibers, enclosed in cirrus pouch along with prostatic duct, with which it eventually unites to form a long eversible cirrus. Prostatic reservoir between ovary and left cecum; prostatic bulb fusiform, with extremely thick wall of oblique muscle fibers, situated between ovary and left testis, with its distal end thrust into base of cirrus pouch and continued into narrow prostatic duct which runs in the cirrus pouch along with the ejaculatory duct. Cirrus pouch unusually long, tubular, extending a long way from genital pore to behind ovary, enclosing ejaculatory duct, prostatic duct and eversible cirrus; its wall consists of inner longitudinal and outer circular muscle fibers for the greater proximal portion but lacks the circular muscle fibers for the distal portion containing the eversible cirrus alone. Cirrus pouch, prostatic bulb and prostatic vesicle are enclosed in a thin-walled common sac, the distal portion of which functions as genital atrium. Latter opening ventrally close to left margin of body beneath left prohaptor. Ovary spherical, a little to right of median line in middle third of body proper. Uterus surrounded by shell gland cells but not enclosed in membranous sac in contrast with that of Benedeniella; eggs with short hook-like polar process. Vagina long, tubular, muscular, opening dorsomarginally well apart from genital pore. Vitellaria coextensive with intestine and its branches; vitelline reservoir well developed immediately in front of ovary. Parasitic on gills of marine fishes.

Genotype: M. hoplognathi n. sp.

\section{Microbothriidae PRICE, 1936}

\section{Pseudomicrobothrium spari n. g., n. sp.}

(Pl. III, Fig. 7)

Habitat: Gills of Sparus macrocephalus (BASILEvSKy).

Material: Some 20 mature specimens fixed in Schaudinn's solution and stained with Heidenhain's hematoxylin.

Locality and date: Sagami Bay; June 6, 1958.

Body $1.4-2.1 \times 0.6-1.1 \mathrm{~mm}$, swollen in greater middle region, narrowed abruptly at level of commencement of vitellaria into a trapezoidal forebody, and produced backward into a short cylindrical haptoral stalk, at the end of which is set a circular, saucer-shaped, opisthohaptor $0.3-0.6 \mathrm{~mm}$ in diameter, with somewhat festooned, nonmuscular border. Cuticle thin and smooth. At the anterior extremity there is a distinct median notch, and on either side of it is a pair of ventroterminal non-muscular pseudosuckers, the inside transverse diameter of which is $0.08-0.13 \mathrm{~mm}$, and the indented border of which stains deeply owing to presence of closely massed adhesive gland ducts. In the neck region behind these pseudosuckers there are two pairs of dorsal eye spots and a ventral mouth, which is immediately followed by globular pharynx $0.1-0.16 \mathrm{~mm}$ in diameter. In the neck and shoulder region there are numerous unicellular adhesive gland cells, whose ducts open along the margin of the pseudo. suckers. The esophagus is practically lacking; the intestine consists of symmetrical limbs with few outer diverticula, each of which is strongly dilated terminally among the vitelline follicles, the last one reaching the base of the haptoral stalk. 
Testis round, with irregular indentations, $0.26-0.45 \times 0.25-0.52 \mathrm{~mm}$, median, equatorial. Vas deferens arising from midde of anterior margin of testis, running forward along left margin of ovary. Seminal vesicle pyriform, $18 \mu$ wide in the type, situated at base of cirrus, with which it is connected by a short narrow duct. In front of the seminal vesicle there are two small elongate tubular prostatic reservoirs each containing fine and coarse granular secretion. Cirrus a long tubule, $0.56-0.6 \mathrm{~mm}$ long by $13-15 \mu$ wide, enclosed in a membranous sheath, forming a transverse loop on right of median line behind pharynx, with its curved point alongside three terminal hooks of accessory piece at genital pore. Accessory piece heavily chitinized, 0.15$0.16 \mathrm{~mm}$ long, consisting of prismatic main portion and three hook-shaped terminal prongs which are close together along with the distal end of the cirrus, their curved tips may or may not project out of the genital pore. Genital pore immediately postbifurcal, median, at about level of base of cirrus.

Ovary subglobular to oval, $0.11-0.14 \times 0.14-0.22 \mathrm{~mm}$, situated immediately in front of testis slightly to right of median line. The germiduct, arising from the ventral surface of the ovary, unites with the vaginal seminal receptacle near its own origin and soon joins the vitelline duct; ootype ventral to left portion of ovary; uterus ventrolateral to vas deferens, no eggs observed. Vitelline follicles comparatively large, distributed in lateral fields of swollen portion of body, approaching median line behind testis; in surface view both dorsally and ventrally they appear as if they were neatly paved, but in some specimens the follicles are dissociated ventrally so as to show the distended cecal diverticula lying underneath. Vitelline ducts dendritic, ventral to vitelline follicles; final paired ducts meeting together ventral to posterior end of ovary. There is a slit-like vaginal apperture on the ventral surface near the right body margin at a preovarian level; the vaginal duct proceeds from this pore obliquely backward toward the ovary, at the right end of which it forms a seminal receptacle, which extends transversely on the ventral surface of the right posterior portion of the ovary. Excretory system not made out.

This genus resembles Microbothrium OLSsON, 1869, in general anatomy, but differs from it in possessing two open bothria-like anterior pseudosuckers and simple, not dendritic, cecal branches, and in lacking a cirrus pouch.

\section{Pseudomicrobothrium n. g.}

Generic diagnosis.-Microbothriidae, Microbothriinae. Body swollen in middle region. Prohaptor in form of paired, non-muscular, bothria-like pseudosuckers which open widely anteroterminally. Opistohaptor a non-muscular, saucer-shaped organ at posterior extremity. Two pairs of eye spots present; pharynx well developed. Intestinal crura with unbranched lateral diverticula, terminating behind testis. Testes single, equatorial. Seminal vesicle and prostatic reservoirs present. No cirrus pouch. Copulatory apparatus consisting of a very long, simple, sheathed cirrus and an accessory piece. Genital pore median, postbifurcal. Ovary slightly submedian, immediately pretesticular, with shell gland complex on its ventral side, uterus short, eggs? Vagina single, dextral, opening at a preovarian level; receptaculum seminis vaginae present. Vitellaria extending in lateral fields from level of genital pore to cecal ends. Parasitic on gills of marine teleosts.

Genotype: P. spari n. sp. 
Udonellidae TASCHENBERG, 1879

\section{Udonella caligorum Johnston, 1835}

(Pl. III, Fig. 1)

A number of mature and gravid specimens were found attached on the dorsal surface of the carapace of an argulid parasitic on Spheroides rubripes in the Aquarium of Tokyo University at Shinmaiko.

Since this species has been inadequately described and figured by previous authors I deem it necessary to redescribe it in detail on the basis of my own specimens which were fixed in Schaudinn's solution under cover glass pressure and stained with iron-hematoxylin.

Body flat, subcylindrical or somewhat fusiform, $1.6-2.35 \mathrm{~mm}$ in length inclusive of opisthohaptor, $0.4-0.56 \mathrm{~mm}$ in maximum breadth at utero ovarian level. Cuticle finely striated transversely; when contracted the attenuated neck or the prehaptoral region may show distinct annular corrugations. Opisthohaptor saucer-shaped, $0.2-0.35 \mathrm{~mm}$ in transverse diameter, with well developed muscles radiating from the shallow central pit, entirely devoid of chitinous holdfast apparatus. The elongate unicellular adhesive glands containing fine secretory granules are seen on each side of the body immediately behind the posteriormost vitellaria; their collecting ducts are strongly winding and join together in the median line behind the cecal end; the common duct wider than each collecting duet is also winding and proceeds toward the center of the opisthohaptor, where it opens outside. Paired anterior pseudosuckers oval in outline, $65-90 \mu$ long, with ducts of cervical glands openings on the surface. The rounded to pyriform cervical gland masses consisting of variable number of cells according to their size extend on each side of the body from the level of the pharynx to that of the anterior end of the ovary. On the frontal margin between the two pseudosuckers there is a pair of prominent conical sensory papillae. The mouth opening is subterminal, but when the pharynx is protruded, the oral margin is seen surmounting the pharynx in form of a belt-like hood, whose anterior free margin is very finely denticled. Pharynx subglobular to rounded quadriangular, $0.140 .2 \times 0.14$ $0.23 \mathrm{~mm}$, provided along its wide anterior opening with a crown of about 20 conical processes. No esophagus. Intestine a simple tubular sac running backward in dorsal median field to near opisthohaptor.

Testis nearly equatorial, oval to spherical, $0.14-0.23 \times 0.2-0.3 \mathrm{~mm}$. Vas deferens narrow, running forward dorsal to ovary and uterus; seminal vesicle oval to elliptical or pyriform, $25-40 \mu$ wide, situated alongside prostatic reservoir a little behind pharynx, opening into genital atrium by a short narrow duct; cirrus not differentiated. Genital atrium opening midventrally a little behind pharynx. A pyriform prostatic reservoir, $28 \mu$ in diameter and containing dark-staining homogeneous secretion, lies along the seminal vesicle, with a compact mass of prostatic cells immediately behind; its distal end tapers to a short narrow duct which opens into the genital atrium along with the duct from the seminal vesicle. 
Ovary globular to oval, $0.15-0.31 \times 0.2-0.4 \mathrm{~mm}$, situated immediately in front of testis. The germiduct arising from the ventral side of the ovary near its right end proceeds forward and soon joins the common vitelline duct at the anterodextral end of the ovary; the uterine duct proceeds obliquely forward from this junction and then straight forward to receive the ducts from two diffrent groups of shell glands at a short interval; the proximal group is smaller than the distal, and apparently secretes non-granular secretion. After receiving the proximal shell gland ducts from both sides the uterine duct narrows to a short straight duct and then widens abruptly as it receives the ducts of the distal group which contains very fine secretory granules. The uterus proper is a simple, wide, muscular tube, but when gravid its middle portion widens to an elliptical sac which is distended with a large elliptical egg 190-220 $\mu$ long by $90-120 \mu$ wide. The long winding polar filament of the egg lies in the portion proximal to this saccular portion, with its terminal dilatation in the initial ootype into which the distal shell gland ducts open. The terminal portion of the uterus remains tubular even when gravid and opens directly into the genital atrium. Vitellaria divided into numerous large follicles, extending in each lateral field from level of genital pore to near posterior end of intestinal cecum, partly surrounding cecum both dorsally and ventrally; the paired transverse vitelline ducts crossing the ovary on its ventral surface join together near the origin of the germiduct and forms a short, forwardly directed, common duct.

The large excretory pores lie symmetrically on the lateral margins of the body at a preovarian level; the excretory stem is very short and divides into two (an ascending and a descending) collecting vessels running along the side of the body.

In the explanation of her original drawing (Fig. 38) of Udonella caligorum SPROSTON (1946) states that a receptaculum seminis lies below the ovary and leads to the fertilization canal which receives the two vitelline ducts, but I was unable to detect such a seminal receptacle behind the ovary. With regard to the structure of the terminal genitalia she does not give any explanation, though the prostatic complex is obscurely shown in Figs $a$ and $c$. The genital pore is definitely midventral.

\section{Gyrodactyloidea JoHnston et Tiegs, 1922}

\section{Dactylogyridae Вусношоку, 1933}

\section{Microncotrema lateolabracis n. g., n. sp.}

(P1. IV, Fig. 11)

Habitat: Gills of Lateolabrax japonicus Temm. et Schleg.

Material: 16 mature whole mounts, most of which had been more or less macerated. Locality and date: Inland Sea of Japan; May 1 and September 8, 1957.

Body flattened fusiform, with anterior extremity 4-lobed and posterior extremity truncated, $0.9-1.0 \mathrm{~mm}$ long by $0.25-0.3 \mathrm{~mm}$ broad, except for those macerated specimens 
which are up to $2.6 \mathrm{~mm}$ long. The flattened type is about $2 \mathrm{~mm}$ in length with maximum width of about $0.8 \mathrm{~mm}$ at level of testis. Anterior extremity with more or less pronounced median incision in unflattened specimens, with a head organ for each of four lobes and two more between two lobes on the same side. Two pairs of dorsal eye spots at level of mouth aperture, which opens immediately in front of the pharynx. Pharynx 60-90 $\mu$ in diameter, divided into a strongly muscular anterior portion and a less muscular posterior portion. Esophagus short; ceca wide, terminating blindly at about junction of middle with posterior third of body. Opisthohaptor discoid, slightly constricted off from body proper, $0.12-0.15 \mathrm{~mm}$ in transverse diameter (up to $0.3 \mathrm{~mm}$ when flattened) with only one pair of very small median anchors supported by a transverse bar, and 14 simple marginal spiness $44-47 \mu$ long; haptoral hook measuring about 15\% from base to height of curve, with its point directed dorsad; central bar only slightly curved, about $15 \mu$ long. Unicellular cement glands well developed, extending forward in longitudinal series in posttesticular intercecal field; enlarged cement cells or reservoirs occupy most of postcecal area down to haptoral apparatus. The dorsal, lateral and ventral muscle bundles originating from the bases of the marginal spines and median haptoral hooks respectively are strongly developed, especially those which pass along each side of the testis and ovary and are finally divided into individual fibers to be attached to the pharynx.

Testes rounded, $0.1-0.13 \times 0.07-0.12 \mathrm{~mm}$ in unflattened specimens, $0.2 \times 0.26 \mathrm{~mm}$ in the flattened type, nearly equatorial ; vas deferens running forward ventral to ovary near its left border, curving round left cecum in a half-spiral from dorsal to ventral side, turning backward on the left of copulatory apparatus to form a small seminal vesicle, whose attenuated posterior end turns forward to lead into the cirrus at its base. Chitinous copulatory apparatus consisting of a broad-based, slender cirrus 83$88 \mu$ long and terminating in a spoon-shaped expansion, and a likewise slender accessory piece of neary equal length with a hook-like recurved tip. There are two prostatic complexes; the larger, anterior, longitudinal reservoir overlapping the seminal vesicle drains the anterior group of the prostatic cells, while the smaller, tubular, sigmoid duct lying transversely near the base of the copulatory appratus drains the posterior group of the prostatic cells. Genital pore at or behind intestinal bifurcation; when the body is contracted, the cirrus and its accessory piece may project out of this pore.

Ovary oval, $0.09-0.1 \mathrm{~mm}$ long by $0.07-0.09 \mathrm{~mm}$ broad $(0.21 \mathrm{~mm}$ broad in the type), immediately pretesticular. Ootype well developed ventrally between transverse vitelline duct and seminal vesicle; egg, one at a time, oval, without polar filaments; Vitellaria extending along entire length of ceca, not confluent posteriorly; transverse vitelline duct preovarian. Vagina opening dorsally in right submedian line at preovarian level, where the right body margin is distinctly notched; it consists of a bulbous terminal swelling lined with extremely thick cuticle and surrounded by circular muscle fibers, and a cylindrical portion provided with longitudinal and circular muscles; vaginal duct tubular, thin-walled. Along the entire length of the vaginal 
duct run longitudinal muscle fibers in form of a sheath. Receptaculum seminis vaginae ventral to origin of germiduct.

The possession of a pair of unusually small haptoral anchors which are much smaller than the marginal spines is the most outstanding character of this genus, to which the generic name refers.

\section{Microncotrema n. g.}

Generic diagnosis.-Dactylogyridae, Dactylogyrinae: Body flattened fusiform, oculate. Opisthohaptor discoid, slightly constricted off from body proper, with one pair of very minute anchors and 14 much larger marginal spines. Pharynx muscular. Ceca terminating blindly some distance short of posterior extremity. Testis median, equatorial; vas deferens looped around left cecum; seminal vesicle developed by dilatation of terminal portion of vas deferens. Two sets of prostatic complexes present. Cirrus with accessory piece. Genital pore immediately postbifurcal. Ovary immediately pretesticular; shell gland preovarian; eggs oval, without polar filament. Vagina opening dorsal or medial to right cecum in front of ovary, receptaculum seminis vaginae present. Vitellaria surrounding ceca throughout their length. Parasitic on gills of marine teleosts.

Genotype: M. lateolabracis n. sp.

\section{Pseudorhabdosynochs epinepheli n. g., n. sp.}

(Pl. IV, Fig. 18)

Habitat: Gills of Epinephelus akaara (Tемm. et Schleg.).

Material: Two mature specimens.

Locality and date: Inland Sea; September 8, 1957.

Body proper fusiform, $0.5 \times 0.1 \mathrm{~mm}$, tapered posteriorly and then abruptly enlarged into haptor. On the flat side of the narrowest posterior region ${ }^{1 /}$ is a membranous plaque with several arcuate transverse ridges, and immediately in front of this there is a group of forwardly directed rose-thorn-shaped hooks, whose number was unable to determine; they are recognizable on the syntype alone, one on the right and two on the left. The spot where the hooks must have been attached is indicated in the type by condensed structure of the subcuticular tissue. Haptor more elongated transversely than body width, with two large unpaired, rod-shaped, parallel, transverse bars apparently fused with each other at the middle and a pair of dorsal spatulate bars, two (dorsal and ventral) pairs of lateral anchors, and few marginal hooklets. Of the unpaired bars the anterior is $85 \mu$ long and has paired submedian elevations anteriorly and a shallow depression at the middle, and the posterior is nearly straight, a little shorter than the anterior, with a slight median depression posteriorly. The dorsal and ventral anchors are approximately the same length (30-50 $\mu$ ), each having two roots of unequal length and a sharp recurved point, the longer root of the ventral anchor articulating ventrally with the distal end of the paired bar, while the dorsal anchor articulates with the tip of the bar on the inner surface of its flattened shorter

1) Distorted in the type specimen. 
root, so that the shorter root of the ventral anchor and the longer root of the dorsal anchor are not articulate, though a bundle of fine muscle fibers is attached to their tip. Immediately in front of the middle of the unpaired transverse bar is a deeply staining circumscribed area.

Head truncate in front, with three pairs of large rounded head organs, the last pair projecting very prominently. Of the two pairs of eye spots the granules of the anterior pair are scattered. Pharynx oval, $26-28 \times 15-23 \mu$. Ceca wide, not united posteriorly. Testis elongate oval to pyriform, 78-85 $\times 36-44 \mu$, situated a little obliquely just behind ovary. Vas deferens ascending by the side of uterus and leading into fusiform bulbus ejaculatorius, which is $31 \mu$ long by $13 \mu$ wide in the type, provided with a thick coat of spiral muscle fibers, and situated very close to the genital pore. Cirrus with a large bulbous basal portion, which is $52 \mu$ long by $23-20 \mu$ wide, and whose lumen is divided into four compartments, of which the largest distal one is produced into a curved hollow spicular filament. A longitudinally elongated prostatic reservoir lies on the left of the uterus, its narrow duct describes a sigmoid curve near the anterior end of the reservoir and finally opens into the basal portion of the cirrus along with the short narrow duct from the ejaculatory bulb. Genital pore some distance (about $60 \mu$ in the type) posterior to intestinal bifurcation.

Ovary oval, $49 \times 31 \mu$ in the type, postequatorial, a little to right of median line. The germiduct arising from the anterior end of the ovary turns toward the median line and joins the vaginal duct and then the transverse vitelline duct about the midbody; uterus subcylindrical, containing a large elliptical egg which is $62-67 \mu$ long by $33-41 \mu$ wide, with marked thickening at posterior pole. Vitellaria co-extensive with intestine, confluent dorsal to intestinal bifurcation and posterior to testis; no vitelline reservoir. Vagina with funnel-shaped opening ventral to left cecum a little behind level of genital pore; vaginal duct narrow, convoluted and well chitinized for its greater distal portion, but its narrow proximal portion is not chitinized and difficult to see but can be traced down to the germiduct.

In Rhabdosynochus Mizelle et Blatz, 1941, the adhesive plaques are lateral, the cirrus has an accessory piece and the vagina is absent, whereas in the present genus the adhesive plaques are dorsal and ventral, the cirrus has no accessory piece and the vagina is present. In both genera the unpaired transverse bars are fused at their mid-regions, and there are some spines on the body.

\section{Pseudorhabdosynochus n. g.}

Generic diagnosis.-Dactylogyridae, Diplectaninae: Body fusiform, spined on each flat surface at posterior tapering portion. Squamodiscs on dorsal and ventral side of haptoral peduncle, each reduced to a membranous plaque with several curved transvdrse ridges. Haptor transversely elongated, with two long slender, unpaired, transverse bars fused at middle, a pair of dorsal bars each articulating with two similar lateral anchors, and few marginal hooklets. Three pairs of head organs and two pairs of eye spots present. Ceca not united posteriorly. Testis postovarian, bulbus ejaculatorius and prostatic reservoir present. Cirrus complex in structure, without accessory piece. Genital pore a little posterior to intestinal bifurcation. Ovary compact, 
postequatorial; uterus wide, simple; eggs with polar thickening. Vitellaria co-extensive with intestine. Vagina present. No seminal receptacle. Parasitic on gills of marine teleosts.

Genotype: P. epinepheli n. sp.

\section{Geneticoenteron lateolabracis n. g., n. sp.}

(P1. IV, Fig. 16)

Habitat: Gills of Lateolabrax japonicus Temm. et Schleg.

Material: A number of mature specimens stained and mounted in toto.

Locality and date: Inland Sea of Japan; April 28, 1957.

Body spatulate, $0.65-1.0 \mathrm{~mm}$ long by $0.22-0.3 \mathrm{~mm}$ broad. Opisthohaptor discoid, about $0.2-0.24 \mathrm{~mm}$ in transverse diameter, well constricted off from body proper. Haptoral anchors consisting of two pairs of hooks and an unpaired median and paired submedian supporting rods; median rod V-shaped, 31-38 $\mu$ long; submedian rod 28$32 \mu$ long, with its blumt-pointed, forwardly curved, outer end articulated with shorter root of ventral hook medially; dorsal hook $27-28 \mu$ long from anterior end of its rod-shaped root to height of curve, with wing-like subapical expansion, with which it is articulated with the nodular protuberance arising from the posterolateral corner of the submedian connecting rod; ventral hook 30-33 $\mu$ long from anterior end of longer root to height of curve, bifid at base, with its shorter root articulated laterally with inner surface of curved outer end of submedian rod as mentioned above. Marginal hooklets about $10 \mu \mathrm{long}$, their number is unable to make out. Cement glands and ducts confined to haptor. Several head organs arranged along anterolateral margin of head. Two pairs of eye spots dorsal to mouth opening. Pharynx somewhat pear-shaped, $55-80 \mu$ in diameter, consisting of a small anterior muscular portion and larger glandular posterior portion, on each side of which is a compact mass of pharyngeal gland cells. The pharyngeal gland ducts are bundled and running along the lateral and posterior borders of the pharynx open into the pharynx at its posterior end. Esophagus very short; ceca wide, with sinuous walls, terminating blindly at posterior end of body proper.

Testis small, oval, $50-90 \times 30-50 \mu$, situated immediately behind ovary at junction of middle with posterior third of body. The vas deferens runs forward ventral to the ovary near its left border, and then alongside the uterus, and after forming a loop around the dorsal side of the genital pore opens into the cirrus along with the prostatic duct. There is only one prostatic complex; the tubular prostatic duct or reservoir crosses the vas deferens ventrally at the level of the anterior end of the genital pore. Cirrus a curved plate with its backwardly directed distal margin armed with four pointed denticles ventrally; a longitudinal muscle bundle extends on the concave side from one end to the other. Genital pore longitudinally elongated oval and measuring $35 \mu$ in transverse diameter in the type, situated at second sixth of body, $0.15-0.3 \mathrm{~mm}$ from anterior extremity. 
Ovary retort-shaped, $0.08-0.1 \mathrm{~mm}$ in diameter, situated in midregion of body immediately in front of testis with its attenuated distal end medial to right cecum, where the germiduct abruptly turns to the left, and is continued beyond its junction with the vitelline duct into a genito-intestinal duct opening into the left cecum at the same level. The shell gland lies immediately behind the transverse germiduct; the uterus passes across this germiduct dorsally and runs straight forward along the vas deferens to open outside by a common genital pore. Eggs, observed in one specimen only, is oval and $44 \mu$ in diameter in collapsed condition, and possesses no polar filament. Vitellaria profusely developed in lateral fields from behind pharyngeal glands to posterior end of body proper, intruding into dorsal median field between genital pore and ovary as well as posterior to testis. No vagina.

This genus, apparently belonging to the Tetraoncinae, is characterized by the two pairs of haptoral anchors being supported by a median and two submedian transverse bars, and the possession of a genito-intestinal duct instead of vagina. The presence of germ cells in the lumen of the left cecum, observed in most of the flattened specimens, is due to the pressure exerted on the cover slip, indicating the direct communication between the germiduct and the left cecum. This is of unique occurrence in the subfamily Tetraoncinae. The generic name refers to the communication between the germiduct and the cecum.

\section{Geneticoenteron n. g.}

Generic diagnosis.-Tetraoncinae: Body spatulate, nearly parallel-sided, oculate. Opisthohaptor discoid, with marginal hooklets; haptoral hooks of two pairs, articulated with paired submedian transverse bars, each of which, in turn, is articulated medially with the V-shaped median bar. - Pharynx consisting of anterior weakly muscular and posterior glandular portions; pharyngeal glands situated in front of anterior end of vitellaria, opening at posterior end of pharynx. Ceca terminating blindly at posterior end of body proper. Testes immediately postovarian; vas deferens not looped around left cecum, and not forming a definite seminal vesicle. Cirrus complex, without accessory piece; prostatic reservoir single. Genital pore median, postbifurcal. Ovary in midregion of body, immediately pretesticular. Genito-intestinal duct present, no vagina. Shell gland immediately behind transverse germiduct. Eggs oval, without polar filaments. Vitellaria lateral and dorsomedian. Parasitic on gills of marine teleosts.

Genotype: G. lateolabracis n. sp.

\section{Murraytrematoides ditrematis n. g. n. sp.}

$$
\text { (Pl. IV, Fig. 14) }
$$

Habitat: Gills of Ditrema temmincki BLEEKER.

Material: Numerous mature and gravid specimens.

Locality and date: Inland Sea ; September 7, 1957.

Body subcylindrical, flattened, $0.4-0.57 \times 0.12-0.19 \mathrm{~mm}$. Opisthohaptor well constricted off from body proper, about $0.15 \mathrm{~mm}$ wide in the type $0.5 \mathrm{~mm}$ long by $0.17 \mathrm{~mm}$ wide, marginal hooklets simple, about $8 \mu$ long, their exact number not made out; central bar V-shaped, $65-78 \mu$ from end to end linearly, paired submedian transverse 
bars $41-52 \mu$ long, with its forwardly directed horn-like outer end articulating with the dorsal root of the ventral anchor and provided dorsally at the base of this horn with a minute knob, with which the shorter dorsal root of the dorsal anchor articulates; dorsal anchor $46-65 \mu$ from end of longer ventral root to height of curve; ventral anchor $56-62 \mu$ from end of ventral root to height of curve.

Anterior extremity rounded, with head organs arranged in an oblique row on each side, behind which the head gland cells are closely massed together. Two pairs of eye spots present. Mouth funnel-shaped, subterminal. Pharynx rounded or longer than broad, $30-50 \times 30-40 \mu$; esophagus practically absent. Ceca simple, terminating blindly near posterior end of body proper, usually close to each other.

Testis irregular in outline, $36-78 \times 39-78 \mu$, situated immediately behind ovary between two intestinal crura; the vas deferens arising from the anterior end of the testis runs forward dorsal to the ovary and after looping around the left cecum passes obliquely forward across the germiduct and uterus dorsally and forms a small oval seminal vesicle $(30 \times 24 \mu$ in the type); the ejaculatory duct, greatly dilated dorsal to the cirrus and metraterm, turns backward immediately behind the intestinal bifurcation, where it joins the prostatic reservoir coming from behind, and after a tortuous descending course opens into the base of the cirrus. Prostatic reservoir tubular, parallel to dilated ascending portion of ejaculatory duct, $42 \mu$ long by $7 \mu$ wide in the type, with its proximal end directed backwards. Prostatic cells massed together immediately in front of distal end of ovary. Cirrus chitinous, consisting of a tricuspid hood-like apex which tapers toward the base in a gentle curve with a muscle bundle extending from base to apex in the concavity. No accessory piece. Genital pore round, provided with few circular and radial muscle fibers, opening midventrally close behind intestinal bifurcation.

Ovary $0.1-0.14 \times 0.065-0.11 \mathrm{~mm}$, situated immediately in front of testis, occupying whole breadth of intercecal area with its long axis parallel to that of body, and its posterior end incised in the median line to enclose the produced anterior end of the testis; the tapering anterior end of the ovary turns round the right cecum, and is continued into a narrow transverse germiduct, which enters the seminal receptacle from the right side and soon emerging close behind its entrance joins the vitelline duct at it crosses the germiduct dorsal to the origin of the latter, where the shell gland cells are converged. The uterus functioning as ootype, is considerably dilated; in the type it is oval and about $40 \mu$ wide, and contains an immature egg $52 \mu$ long by $39 \mu$ wide; the terminal portion of the uterus is differentiated into a metraterm provided throughout with a number of longitudinal internal cuticular folds and a dense coat of glandular cells; in some specimens this metraterm is seen completely evaginated to the outside. It appears, therefore, that this structure serves as an ovijector sui generis. Eggs oval, without polar filament, about $45 \mu$ in diameter in mounted condition. Vagina lined with cuticle, with a slit-like ventral opening in left submedian line at level of anterior end of ovary; it opens internally into the seminal receptacle, which in turn joins the germiduct on its right side as mentioned above. Vitellaria 
extending in lateral fields from level of pharynx to posterior end of body proper, intruding into posttesticular intercecal field.

This genus bears a certain resemblance to Murraytrema PRICE, 1937, but provided that MURRAY's description be correct, the present genus differs from it in the following essential characters.

1. The vas deferens loops around the left cecum.

2. The prostatic reservoir opens into the ejaculatory duct, and not directly into the cirrus.

3. The ovary loops around the right cecum.

4. The vagina opens ventrally in the left submedian line at the level of the anterior end of the ovary.

5. The unpaired median haptoral bar articulates with the paired bars at its lateral arms.

6. Each marginal haptoral hooklet has a single claw.

Further, the present species differs from Murraytrema pricei Caballero, Bravo et GROCOTT, 1955, which undoubtedly belongs to the genus under consideration, in the cephalic region not being delimited from the body proper, in the vas deferens encircling the left cecum, etc. The latter character, however, may have been overlooked in Murraytrema pricei.

\section{Murraytrematoides $\mathrm{n} . \mathrm{g}$.}

Generic diagnosis.-Dactylogyridae, Tetraoncinae. Opisthohaptor with a median and two submedian transverse bars, two pairs of nearly similar anchors, and a number of marginal hooklets. Several pairs of head organs and 2 pairs of eye spots present. Intestinal crura simple, not confluent posteriorly. Testis irregular in outline, postequatorial. Vas deferens encircling left cecum; seminal vesicle formed by mere dilatation of vas deferens. One prostatic reservior present. Cirrus complex in structure, without accessory piece. Ovary tapering distally and encircling right cecum, pretesticular. Vagina opening ventrally in left submedian line at level of anterior part of ovary. Seminal receptacle present. Eggs oval, without filament (?). Vitellaria extending in lateral fields from level of pharynx to posterior end of body proper. Parasitic on gills of marine teleosts.

Genotype: $M$. ditrematis n. sp.

Other species: M. pricei (CABALlero, Bravo et GrocotT, 1955) n. comb., on Muraenesox coniceps; Canal Zone (Pacific).

\section{Pseudomurraytrema spari n. g., n. sp.}

(Pl. IV, Fig. 17)

Habitat: Gills of Sparus macrocephalus BASILEwSKy.

Material: Four mature specimens.

Locality and date: Inland Sea; September 9, 1957.

Body subcylindrical, flat, oculate, $1.0-1.23 \times 0.15-0.3 \mathrm{~mm}$. Opisthohaptor well set off from body proper, discoid, with median incision posteriorly, $0.19 \mathrm{~mm}$ wide in the type $1.23 \mathrm{~mm}$ long, with 14 marginal hooklets and a pair of slender sigmoid transverse bars 
which are $28 \mu$ long, each provided at its outer curved portion with two minute supporting rods $15 \mu$ and $13 \mu$ long respectively. The paired portions bearing the bars are somewhat elevated ventrally, each containing a large cement reservoir. There is no central bar between the paired transverse bars. Cement glands strongly developed in posterior intercecal field.

Head approximately trapezoidal, $0.15 \mathrm{~mm}$ in diameter in the type with median notch anteriorly. Head organs conspicuous with their gland cells massed together lateral to eye sports. Mouth opening ventrally between two pairs of eye spots. Pharynx $80-100 \mu$ in diameter; pharyngeal cells massed together anterior and lateral to anterior end of vitellaria; esophagus practically lacking, ceca wide at bifurcation, terminating blindly near posterior extremity of body proper.

Testis longitudinally elongated oval, $0.22-0.28 \times 0.15-0.25 \mathrm{~mm}$, situated in middle third of body, occupying entire breadth of body. Vas deferens turning round left cecum, forming twisted seminal vesicle ( $33 \mu$ wide in the type) medial to the cecum. There is a retort-shaped prostatic reservoir ( $28 \mu$ wide in the type) opening into the cirrus at its base along with the vas deferens; prostatic cells massed together immediately in front of ovary medial to right cecum. Cirrus strongly curved, measuring 44-52 $\mu$ linearly from obliquely truncated funnel-shaped base to acicular point; accessory piece approximately $\mathrm{T}$-shaped, about $50 \mu$ long linearly from acute tip of longer arm to slightly swollen distal point, lying alongside cirrus, with muscle fibers extending from tip of base of cirrus to curved shorter arm of accessory piece. Genital pore median, a little (about $80 \mu$ in the type) behind intestinal bifurcation.

Ovary tubular, pretesticular, encircling right cecum, curved at right angles with compact mass of shell gland cells between its two extremities. Uterus simple, short; no eggs observed. Vitellaria extending profusely in lateral fields, surrounding ceca, confluent in median field dorsal and posterior to intestinal bifurcation, between ovary and testis and posterior to testis. Vitelline reservoir transversely elongated, resting on ventral surface of proximal portion of ovary. Vagina well chitinized, narrow, funnelshaped, opening middorsally at level of anterior part of testis; vaginal duct narrow, opening into fusiform or retort-shaped seminal receptacle which lies across the ventral surface of the proximal part of the ovary alongside the vitelline reservoir and joins the germiduct at its medial end. Paired excretory vesicles opening dorsally at level of posterior end of pharynx.

This species resembles Murraytrema robustum (MURRAY, 1931) in the ovarian complex and terminal genitalia, and Murraytrematoides ditrematis mihi in the ovary and vas deferens encircling the intestine, but differs fundamentally from either in the haptoral anchors. There is no central bar in the present species and the anchors associated with the paired bars are so much reduced that they are no more functional anchors. That the vagina opens dorsally unlike that of Murraytrema robustum is worth noting.

\section{Pseudomurraytrema n. g.}

Generic diagnosis:-Dactylogyridae; Tectraoncinae: Body subcylindrical, flat, oculate. Opisthohaptor well set off from body proper, with 14 marginal hooklets, a pair of slender 
transverse bars each associated with rudimentary anchors, and a pair of conspicuous cement reservoirs. Head organ complex and pharyngeal glands well developed. Two pairs of eye spots present. Intestinal crura simple, teminating blindly near posterior extremity. Testis oval, large, in middle third of body; vas deferens encircling left cecum, dilated medial to left cecum to form tortuous seminal vesicle. Prostatic reservoir opening into cirrus along with vas deferens. Cirrus with accessory piece. Genital pore median, postbifurcal. Ovary pretesticular, tubular, curved, encircling right cecum; uterus simple; eggs? Vitellaria extending in lateral fields, confluent in median field dorsal and posterior to intestinal bifurcation, between ovary and testis and posterior to testis. Vagina opening middorsally at level of testis; seminal receptacle well developed. Parasitic on gills of marine teleosts.

Genotype: P. spari n. sp.

\section{Pseudamphibdella paralichthydis n. g., n. sp.}

(Pl. III, Fig. 6)

Habitat: Gills of Paralichthys olivaceus Temm. et Schleg.

Material: Three mature specimens.

Locality and date: Inland Sea; September 12, 1957.

Body very small, flattened subcylindrical, tapering toward opisthohaptor which is 4-lobed, $0.11 \mathrm{~mm}$ in diameter and well set off from the body proper. Four symmetrical lobes of opisthohaptor separated one from another by a median longitudinal and a transverse groove, two being dorsal and others ventral, each bearing a strongly curved anchor about $31-33 \mu$ long from tip of longer root to height of curve and marginal hooklets $10-13 \mu$ long; a claviform cement reservoir is seen close to each anchor with its attenuated distal end directed toward the point where the anchor projects over the surface of the lobe; large claviform cement gland cells are massed together at posterior end of body proper.

Head trapezoidal, $0.1-0.11 \mathrm{~mm}$ wide, with a group of closely massed head organs on each side. Two pairs of eye spots present. Pharynx $52-78 \times 47-60 \mu$, apparently constricted into two portions; anterior portion consisting of a circle of six large cells each containing a large nucleus, posterior portion composed of very fine muscle fibers; pharyngeal gland cells posterolateral to pharynx, their ducts converging toward posterior end of pharynx and opening into pharyngeal lumen at anterior end of posterior portion of pharynx. Esophagus practically absent; ceca simple, terminating blindly short of posterior end of body proper.

Testis ovoid, $28-39 \times 39-55 \mu$, situated immediately behind ovary; vas deferens looped round left cecum anterolateral to ovary. No seminal vesicle. Prostatic reservoir oval, at base of cirrus. Cirrus acicular, surrounded at base by muscle fibers. Genital pore circular, just postbifurcal.

Ovary rounded, $65-78 \times 65-100 \mu$, just postequatorial. The germiduct arising from the anterior end of the ovary turns back on itself and forms an oval dilatation, where it joins the vitelline duct coming from the transverse commissure, and then receives the shell gland ducts. Shell gland cells massed together anterior to ovary. Uterus divided into a short cylindrical proximal portion and a large oval distal portion, the 
latter containing in the type a crumpled egg whose polar filament extends straight backward with its somewhat enlarged tip in the above mentioned dilated portion of the germiduct. Neither vagina nor seminal receptacle. Vitellaria extending along ceca from level of pharynx to beyond cecal ends, confluent across median line in front of genital pore as well as in posttesticular intercecal field; paired vitelline ducts passing ventral to proximal portion of uterus.

This species bears a certain resemblance to Amphibdella torpedinis CHATIN, 1874, in the character of haptoral anchors, but differs from it in lacking a vagina and seminal receptacle, in the relative position of the ovary and testis, in the anterior extent of the vitellaria, etc. There is no doubt whether it represents a new genus of the subfamily Tetraoncinae.

\section{Pesudamphibdella n. g.}

Generic diagnosis.-Dactylogyridae, Tetraoncinae: Body very small. Haptor well constricted off from body proper, with four (two dorsal and two ventral) symmetrical lobes, each lobe bearing a strongly curved anchor and minute marginal hooklets; cement gland complex well developed. Head organ, pharyngeal glands and two pairs of eye spots present. Ceca simple, not united posteriorly. Testis postovarian; vas deferens looped round left cecum. Single prostatic reservoir present. Cirrus acicular, without accessory piece. Genital pore postbifurcal. Ovary comparatively large, pretesticular. Eggs with polar filament. Neither vagina nor seminal receptacle. Vitellaria co-extensive with intestine, confluent anterior to genital pore and posterior to testis. Parasitic on gills of marine teleosts.

Genotype: $P$. paralichthydis n. sp.

\section{Megaloncidea n. superfam.}

MEgaloncidae n. fam.

\section{Megaloncus arelisci n. g., n. sp.}

(Pl. III, Figs. 2-3)

Habitat: Gill of Areliscus joyneri (GüNTHER).

Material: Three gravid specimens fixed under cover glass pressure, stained with Heidenhain's hematoxylin and mounted in toto.

Locality and date: Inland Sea; March 15, 1958.

Body proper flattened fusiform, $0.37-0.5 \mathrm{~mm}$ long, $0.94-1.0 \mathrm{~mm}$ wide about middle, produced backward into a short stalk, to which an elongate, dorsally convex haptor is attached. Cuticle scattered all over with minute cuticular papillae, which are more numerous at the anterior extremity than elsewhere. Eye spots absent. Haptor 1.2$1.3 \mathrm{~mm}$ long, provided on the concave ventral side at certain intervals with three pairs of very powerful anchor complexes, each of which consists of a stout, prismatic basal piece, a basally three-toothed, principal claw with two unequal spine-like processes on concave side and two poorly chitinized saddles on other side near its base, and a nearly straight hollow bar which has a poorly chitinized saddle near its 
base and a small hammer-shaped tip surmounted by a T-shaped accessory piece; the principal claw and hollow bar articulate with the four-toothed apex of the basal piece; the two teeth of the latter interlocking with the two basal teeth of the principal claw, with the other two teeth in direct contact with the remaining tooth of the claw as well as with the two basal teeth of the hollow bar. This fundamental structure of the anchor complex and the mode of articulation are all alike in the three pairs, though distal end of the dorsal saddle of the first and second principal claws is single-barbed while that of the third claw is double-barbed, and the ventral saddle is lacking (?) in the third pair. Measurements in $\mathrm{mm}$ of length (linearly from end to end) of each anchor pair are as follows:

\begin{tabular}{l|l|l|l}
\hline \multicolumn{1}{c|}{ pair } & \multicolumn{1}{|c|}{ I } & \multicolumn{1}{|c}{ II } & III \\
\hline component & $0.28-0.31$ & $0.31-0.4$ & $0.25-0.32$ \\
Principal claw & $0.14-0.2$ & $0.17-0.22$ & $0.18-0.2$ \\
Hasal support & $0.2-0.25$ & $0.2-0.25$ & $0.19-0.2$ \\
Accessory piece of bar & $0.07-0.09$ & 0.095 & 0.085 \\
\hline
\end{tabular}

At the posterior end of the body proper there are profusely developed small unicellular gland cells, probably serving adhesive purposes.

Mouth subapical. A pair of strongly muscular anterior suckers present, each measuring $65-70 \mu$ in diameter, with a transverse septum. Pharynx pyriform, $75-85 \times$ 60-67 $\mu$. Esophagus with few lateral branches; at this level there is on each side a compact mass of unicellular gland cells. Intestine with narrow lateral branches, which are confined to the vitellarian area and dilated at the outer end reaching to the lateral edge of the body; each cecum is continued into the haptor as a narrow simple duct which extends near the dorsal cuticle as far back as the posterior end of the haptor, giving off at nearly right angles three, narrow, simple, lateral branches, each of which reaches to the base of each haptoral anchor complex. These cecal continuations are accompanied all the way through by light brown pigment granules, which in the fresh state clearly indicate the course of the ducts.

Testes small, subglobular to oval, paved in one layer in median field posterior to ovarian complex, overlapping vitelline follicles laterally but not extending backward beyond posterior limit of vitellaria; their number is unable to count with certainty. Vas deferens running almost straight forward in median field on the right of shell gland and then between vitelline duct and ovary, anterior to which it may be distended with spermatozoa to a maximum width of $40 \mu$ and follows a winding ascending course dorsal to the median uterus; its distal portion tapers again as it approaches the ejaculatory duct, which is very narrow and short and provided with circular muscle fibers ; cirrus forming an unarmed muscular bulb about $65 \mu$ in diameter, and opening directly into atrial sucker. Latter ovoid, $67-70 \mu$ in transverse diameter, armed at its opening with a circle of 6 hooks, the convex side of which is fluted longitudinally. 
Genital pore opening outside just in front of this genital sucker, at about level of anterior end of vitellaria. .

Ovary vermiform, folded back on itself with proximal end directly behind distal end, on the right of median line, measuring $0.37-0.5 \times 0.32-0.52 \mathrm{~mm}$ as a whole, situated at second sixth of body proper. The germiduct lined with ciliated epithelia arises from the distal end of the ovary and winds its way backward dorsal to the proximal end of the ovary, and forms a peculiar narrow fusiform swelling, toward which are converged numerous fine, gland-duct-like striae, and into which open a number of radial tubular seminal receptacles surrounded by circular muscles; some of these seminal receptacles are dilated at their blind end to form typical seminal sacs of varying dimensions, the largest in the type specimen measuring $90 \mu$ in diameter and lying posterior to the point of origin of the genito-intestinal duct. This duct arises from the germiduct just behind the above mentioned fusiform swelling and passes obliquely forward to open into the right cecum. After joining the common vitelline duct, the germiduct turns back on itself and leads into the elongate ootype lying on the left of the median line dorsal to the common vitelline duct. Uterus ventral to ovary and vas deferens, containing one to three eggs; eggs fusiform, produced at each pole into a process about $0.15 \mathrm{~mm}$ long. Vitelline follicles profusely developed on each side of body from level of genital pore to near posterior end of body proper, almost confluent in median field anterior to ovary, but leaving the postovarian median field free for the testes; the common vitelline duct arising from the right submedian vitellaria at the level of the anterior end of the ovary winds its way obliquely backward ventral to the ovary, vas deferens, uterus and sheil gland complex and unites with the germiduct a short distance (about $0.1 \mathrm{~mm}$ in the type) from the origin of the genitointestinal duct. Vagina absent. Excretory vesicles situated symmetrically, one on each side of bulbus cirri or genital sucker.

This genus is characterized by the enormous development of the posterior haptoral apparatus consisting of three pairs of anchor complexes, the components of each complex articulating with one another. That the germiduct forms a very peculiar fusiform swelling into which open a number of tubulo-saccular seminal receptacles is also worth noting. From the structure of the opisthohaptor it is certain that this genus belongs in the suborder Monopisthocotylea ODHNER, 1912, but in other characters it bears a marked resemblance to microcotylids without vagina of the suborder Polyopisthocotylea ODHNER, 1912, only differing in the organogenesis of the seminal receptacle. So far as I am aware this organ has been observed to originate from the germiduct in Cyclobothrium Cerfontaine, 1895 and some species of Microcotyle Ben. et HESSE, 1863.

In view of these considerations it seems very likely that the present genus shows a linkage between the two suborders Monopisthocotylea and Polyopisthocotylea, but from the fundamental structure of the opisthohaptor as a single unit, to which suborder importance is ascribed, I prefer to assign this genus to Monopisthocotylea, and to propose a new superfamily Megaloncidea, with the following diagnosis. 


\section{Megaloncidea $\mathrm{n}$. superf.}

Superfamily diagnosis.-Monopisthocotylea: Functional opisthohaptor developed as a single unit in form of an elongate bolster armed with 3 pairs of anchor complexes, each of which consists of a powerful principal anchor interlocking with its basal support and an apically disconnected bar; no marginal hooklets. Prohaptor represented by paired intrabuccal accessory suckers and well developed glandular area. Genitalia of microcotylid type in general pattern, without vagina. Receptaculum seminis arising from germiduct. Parasites of teleosts.

\section{Megaloncidae n. fam.}

Family diagnosis.-Megaloncidea: With characters of superfamily.

\section{Megaloncus $\mathrm{n}$. g.}

Generic diagnosis.-Megaloncidae: Opisthohaptor elongate, convex dorsally, without marginal hooklet; principal claw long; with two spinelike processes on its slightly concave side and two poorly chitinzed saddles on other side near the base; its basal support stumpy, prismatic, interlocking with principal claw and also articulating with another rather straight hollow bar whose hammer-shaped tip is surmounted by T-shaped accessory piece. Body proper covered with numerous cuticular papillae; anterior extremity with well developed glandular area; eye spots absent. Mouth ventroterminal, two septate oral suckers in buccal cavity; pharynx pyriform, esophagus with side branches; Intestine also with numerous narrow lateral branches, each cecum continued backward to posterior end of opisthohaptor as a simple narrow duct giving off three similar lateral branches, one for each anchor complex. Testes divided into numerous small follicles, in postovarian median field. Vas deferens winding in median line anterior to ovary; ejaculatory duct differentiated but very short; cirrus in form of a muscular bulb; genital atrium with armed basal sucker, at the center of which opens the bulbus cirri; genital pore opening midventrally just in front of this genital sucker at level of anterior end of vitellaria. Ovary vermiform, folded back on itself with both extremities close together; germiduct forming a fusiform swelling, into which open a number of tubulo-saccular seminal receptacles and numerous fine ducts of unknown glands (?). Genito-intestinal duct originating from germiduct just distal to this peculiar swelling and opening into right cecum. Shell gland complex postovarian, left of median line. Uterus running straight forward ventral to winding vas deferens; eggs with polar prolongation at each pole. Vitellaria follicular, co-extensive with intestine and its branches except posterior cecal prolongations intruding into opisthohaptor; common vitelline duct arising from right submedian vitellaria at level of anterior end of ovary, uniting with germiduct before the latter turns back on itself to lead into the ootype. Vagina absent. Excretory vesicles symmetrical, one on each side of bulbus cirri or genital sucker. Parasitic on gills of marine teleosts.

Genotype: M. arelisci $\mathrm{n} . \mathrm{sp}$.

Polyopisthocotyles OdHner, 1912

Diclidophoroidea PRICE, 1936

Diclidophoridae FUHRMANn, 1928

12. Osphyobothrus parapercis n. g., n. sp.

(Pl. III, Figs. 8-9)

Habitat: Gill of Parapercis pulchella TEMm. et Schleg. 
Locality and date: Aquarium of Tokyo University at Shinmaiko, Aichi Pref.; May 14, 1958.

A single mature but not gravid specimen was fixed in Schaudinn's solution under a cover slip after it had been examined in the fresh state, and stained and mounted as usual.

Body tapered anteriorly and enlarged posteriorly, with a wide median sinus at posterior extremity, $2.65 \mathrm{~mm}$ in length from head end to base of posterior sinus, about $1.0 \mathrm{~mm}$ in width at anterior end of haptor. Haptor not set off from body proper, with four pairs of pedunculate clamps of nearly same size. Just in front of the posterior sinus is embedded in the body parenchyma a well defined rounded muscle bulb measuring $0.2 \mathrm{~mm}$ long by $0.18 \mathrm{~mm}$ broad and possessing a longitudinally elongated oval central pit opening on the dorsal surface. This bulb consists of very fine lamellar circular muscle fibers, radial muscle fibers converged toward the opening of the pit, and nine, transversely striated, powerful, longitudinal muscle bands separated from one another by interstitial connective tissue. In the fresh state the bulb was seen actively changing its size and shape by the contraction of the longitudinal muscle bands. Dorsally outside the bulb, especially anterior to the opening of the pit, there are strongly developed circular lamellar muscle fibers, probably associated with the contraction of the bulb.

The chitinous framework of the clamp consists of a $T$-shaped ventral piece with its long arms reaching to the outer basal corner of the clamp skeleton and a similar $\mathrm{T}$-shaped dorsal piece with its long curved arms articulating on each side with a shorter lateral piece arising from each basal corner of the skeleton. A short free piece is given off inwards from the outer corner of the skeleton. The dorsal and ventral median stems are articulated with each other at the base, where they are pushed outward by the dome-like pad, to which the powerful clamp fixer is attached, and which is surmounted by an arcuate chitinous bar connecting the base of the median stems with the inner basal corner of the clamp skeleton. The medial surface of the ventral stem is denticulate as shown by Seroston for Diclidophora merlangi. The non-chitinous walls of the dorsal and ventral valves do not show and particular structure. The gross pattern of the skeleton of the clamp is similar to that of Diclidophora merlangi as illustrated by SPROSTON in her figure $112 \mathrm{f}$, though different in minor details.

In front of the wide subterminal mouth opening is a conical median projection, at the apex of which open the sticky gland ducts close together. At each lateral corner of the mouth aperture opens a bundle of cervical gland ducts coming from the gland cells which are massed together on each side in the neck region. Paired anterior suckers $0.1 \mathrm{~mm}$ long by $0.06 \mathrm{~mm}$ wide, with a wide cleft-like opening ventrally and medially and no septum. A slender muscle bundle is attached to the posteroventral end of each sucker; as it passes by the pharynx it is reinforced by additional fibers, the innermost of which cross each other posteroventral to the pharynx, the 
remaining fibers are dissociated as they run backward and merged sooner or later into the ventral subcuticular muscle layer. Pharynx pyriform, poorly muscular, $0.1 \mathrm{~mm}$ in diameter, with its anterior opening bordered with thick cuticle. Esophagus bifurcating immediately in front of genital pore. Ceca with numerous outer and inner branches, but not confluent posteriorly; one of the left posterior branches, crossing the median line anterior to the above mentioned caudal muscle bulb, runs down to the base of the peduncle of the right posteriormost clamp, parallel to the posteriormost branch of the right side; the outer branches reaching to the lateral edge of the body or the base of the peduncle of each clamp show for the most part a conspicuous terminal dilation. The parietal pigment cells are well developed to the whole extent of the intestine and its branches.

Testes subglobular to oval, or elliptical, about 30 in number, situated in a zigzag row (or irregular double row), mostly in postovarian median field; some of them are seen on the right of the ovary and vitelline reservoir. Vas deferens running straight forward dorsal to uterus, describing. a sigmoid curve before opening into genital atrium by a typical sucker which corresponds to the bulbus cirri, but not to the common genital sucker in the strict sense of the word. This sucker, $39 \times 44 \mu$, consists exclusively of meridional muscle fibers, and has a definite outer limiting membrane, and is lined with cuticle at the central opening, its anterior ventral surface giving a file-like appearance. The genital atrium proper, at the base of which opens the above mentioned sucker, is provided inside near its opening with a ring of eight cuticular tubercles, each of which bears a slightly curved, inwardly directed spine. The relatively small, common, genital pore opens at the center of this armed coronet at a distance of $0.32 \mathrm{~mm}$ from the tip of the frontal projection.

Ovary approximately $\mathrm{W}$-shaped, $0.35 \times 0.38 \mathrm{~mm}$, situated near midregion of body ; its proximal end folded upon itself, and the next middle portion crossing the genitointestinal duct, germiduct, vitelline reservoir and uterus dorsally, the distal portion $0.14 \mathrm{~mm}$ wide is directed forward, giving off the germiduct at its anterior end. The germiduct runs transversely to the right along the convex side of middle portion dorsal to the uterus and vitelline reservoir and then backward, and joins the genitointestinal duct just before crossing the ovary on its ventral side. After crossing the ovary and vas deferens it receives the duct from the vitelline reservoir. There is no receptaculum seminis as observed in Diclidophora merlangi. The elongate fusiform ootype lies ventrally in the free space formed by the arcuate middle portion of the ovary and contains a number of yolk cells and shell material together with a germcell in the process of egg formation. Uterus straight, median, ventral to vas deferens, provided with inner longitudinal and outer circular muscles and lined with long cilia directed forward. Though narrow proximally it gradually widens distally, attaining a maximum diameter of $42 \mu$ before entering the genital atrium ventral to the male terminal sucker. Vitelline follicles occupying all available space of body from level of intestinal bifurcation to base of peduncles of clamps; vitelline reservoir elongate, 
widest at its base where the two vitelline ducts join together, extending longitudinally on the right of uterus and ootype, with its tapered distal portion crossing the ovary on its ventral side. Vagina absent.

This genus bears a marked resemblance to Diclidophora DIESING, 1850, in general anatomy, but differs distinctly in the absence of seminal receptacle and the presence of a muscle bulb opening dorsally at the lower part of the back, to which the new generic name refers.

\section{Osphyobothrus n. g.}

Generic diagnosis.-Diclidophorinae: Body proper undivided, tapered anteriorly and widened posteriorly. Haptor not clearly set off from body proper; clamps pedunculated; the dorsal valve is supported by a $\mathrm{T}$-shaped median piece and a pair of lateral basal pieces articulating with the lateral arms of the median piece, while the ventral median piece sends out a pair of long lateral arms reaching to basal corners of the clamp; the stems of the dorsal and vental median pieces are articulated at the base and pushed outward by the pad, to which the clamp fixer is attached and which is surmounted by an arcuate chitinous bar connecting the base of the median stems with the inner basal corner of the clamp skeleton. A short free piece is given off inwards from the outer basal corner of the skeleton. Just in front of the median posterior sinus of the haptor is an ovoid contractile muscle bulb opening dorsally and containing a number of transversely striated, longitudinal muscle bands. Anterior end of body proper tapering to a small conical projection; mouth subterminal, with wide aperture; cervical glands well developed, with their ducts opening at each lateral corner of mouth aperture; anterior suckers opening widely into mouth cavity, without septum; pharynx weakly muscular. Intestine with numerous inner and outer branches but not confluent posteriorly; posterior outer branches reaching to base of peduncles of clamps. Testes numerous, largely median and postovarian, some of them lateral to ovary and vitelline reservoir. Distal end of male duct modified into sucker which opens into the genital atrium at its base. Genital atrium provided with a coronet of eight cuticular tubercles, each of which bears an inwardly pointing spine. Common genital pore opening at center of this coronet just behind intestinal bifurcation. Ovary approximately W-shaped with its distal end directed forward, situated near midregion of body. No receptaculum seminis. Genito-intestinal duct present. Eggs? Vitellaria co-extensive with intestinal branches; main bulk of vitelline reservoir longitudinally elongated immediately anterolateral to ovary. No vagina. Parasitic on gills of marine teleosts.

Genotype: $O$. parapercis n. sp.

\section{Cyclobothrium semicossyphi Yamaguti, 1938}

Four gravid specimens found in Semicossyphus reticulatus from the Inland Sea gave the following measurements.

Body $1.4-2.2 \times 0.55-0.75 \mathrm{~mm}$. Opisthohaptor $0.45-0.66 \mathrm{~mm}$ in diameter. Genital corona $35-40 \mu$ in diameter. Anterior testes 5-10 in number, posterior testes 12-17. Ovary $0.18-0.2 \times 0.21-0.34 \mathrm{~mm}$. Eggs $120-170 \times 60-65 \mu$.

The seminal receptacle is distinctly septate, rosette-shaped, though not properly illustrated in my original drawing. Clamp similar in fundamental structure to that of the genotype. 


\section{Heterobothrium tetrodonis (GoTO, 1894) CERF., 1895}

Habitat: Gills of Sphaeroides xanthopterus Temm. et SchLEg.

Material: Four mature specimens, of which two were fully gravid, fixed in Schaudinn's solution under cover glass pressure.

Locality and date: Sagami Bay; June 7, 1958.

Since this material is poorly stained, I shall confine myself to a mere supplementary note on the egg and the skeleton of the clamp, which are not described by Goтo.

On the mounted slides the fusiform eggs measured $140-180 \mu$ by $70-90 \mu$, with a long filament at each pole.

The anterior valve of the clamp is supported by a $\mathrm{T}$-shaped median piece, while the posterior valve has an arcuate marginal rod without median stem. The anteromedial basal frame forms a large, approximately rectangular, excavated plate, the anterior inner corner of which is articulated by means of an intercalated piece with the end of the inner arm of the anterior median piece, and the anterior outer corner of which is produced toward the inner end of the arcuate rod of the posterior valve. At the posterior inner corner of the clamp the three-jointed outer arm of the median piece and the arcuate rod are articulated near the base of the latter rod. The T-shaped median piece is articulated at the base on the outer side directly with the posterolateral corner of the above mentioned basal plate, but on the inner side it rests on a small chitinous mass, which in turn fits into the concavity of the bifid protuberance on the inner margin of the basal plate.

\section{Microcotylidae TASCHEnBERG, 1879}

\section{Microcotyle gimpo n. sp.}

(Pl. IV, Fig. 15)

Habitat: Gills of Enedrias nebulosus (Temm. et Schleg.)

Material: One immature and two mature specimens.

Locality and date: Inland Sea; Sept. 9 (type date), April 30, 1957.

Body fusiform, $1.3-2.5 \times 0.35-0.6 \mathrm{~mm}$. Cotylophore with 58 and 64 clamps respectively in two mature specimens, but 32 in immature specimen, clamp skleteton measuring up to $52 \mu$ in diameter, with accessory piece for posterior ramus of middle piece. Anterior extremity rounded, with a middorsal and two paired lateral groups of head organs. Anterior sucker with distinct partition, $30-40 \mu$ in transverse diameter; pharynx $41-62 \times 34-41 \mu$. Esophagus wide, bifurcating immediately behind genital pore ; ceca with numerous outer branches reaching lateral margins of body, left cecum intruding into cotylophore further backward than right one.

Testes 13-18 in number, occupying whole postovarian intercecal field. Vas deferens winding dorsal to uterus; a short pars prostatica surrounded by prostate cells well differentiated, opening directly into posterior portion of genital atrium at tip of 
hemispherical protuberance. Preatrial bulb surrounded by lamellar muscle layer, containing minute granules, opening into genital atrium posteroventrally. Genital atrium divided into reniform anterior portion which is $0.075-0.15 \mathrm{~mm}$ in diameter, surrounded by radial muscles and covered inside with minute spines, and a bowl-shaped posterior portion which is $0.038-0.11 \mathrm{~mm}$ in diameter, sparsely spined on each lateral inner surface, and opens outside ventrally. The dorsal wall of this posterior portion has a shallow circular pit just dorsal to the above mentioned hemispherical protuberance. Genital pore surrounded by radial and circular muscle fibers, lined with folded cuticle.

Ovary shaped like an interrogation mark as usual, with proximal portion resting on anteriormost testes, $0.2-0.28 \mathrm{~mm}$ anteroposteriorly, situated at broadest part of body. Germiduct convoluted, forming cylindrical seminal receptacle just before giving off genito-intestinal duct, which proceeds obliquely forward along the posteroventral border of the seminal receptacle. Shell gland situated on the left of posterior end of unpaired vitelline duct. Uterus dorsosinistral to unpaired vitelline duct, crossing left vitelline duct ventrally. Egg fusiform, thick-shelled, $0.13 \mathrm{~mm}$ long by $56 \mu$ broad, tapering into a short blunt-pointed process at one end and a longer pointed process at the other. Vitellaria surrounding ceca and their branches; paired vitelline ducts joining together anterior to ovary. Vagina elliptical, opening middorsally at a distance of $0.3-0.32 \mathrm{~mm}$ from anterior extremity; vaginal duct extending sinuously in dorsal median field from vagina to middle of transverse commissure of paired vitelline ducts. Paired lateral excretory pores at level of genital pore.

This species is characterized by the pars prostatica directly opening into the genital atrium at the tip of a hemispherical protuberance.

\section{Microcotyle sciaenae GoTo, 1894}

18 mature specimens of this species were found on the gills of Nibea schlegeli (BleEker) (=Sciaena sina) from Sagami Bay, June 6, 1958. As compared with Gото's original description the present material agrees completely in the most important specific characters, especially in the armature of the genital atrium, but differs in some points of minor significance which are given below.

The esophagus is shown in Goto's figure 6 as a simple narrow tube, but in all the specimens at my disposal it has two or more outpocketings on each side, and the intestinal limbs with numerous outer and inconspicuous inner branches terminate in the cotylophore at distinctly different levels, left one being the longer with only one exception. Goтo says, "No branches on the median side of the intestine, the two trunk of which extend far into the caudal disc and are in this region wholly destitute of lateral branches; the right trunk describing a larger curve in consequence of the general asymmetry of the body".

The asymmetrical cotylophore bears more numerous clamps on the right side than on the left or vice versa without any definite correlation with the side on which the longer cecum occurs; 58-86 clamps (75 after GoTo) in the longer row, and 56-75 
clamps (60 after Goto) in the shorter row, the total number varying from 114 to 157. The number of the testes varies from 13 to 30, whereas Goto gives it as about 29 .

The measurements made on the present material which was subjected to cover glass pressure when fixed in Schaudinn's solution are as follows:

Body $3.1-4.4 \mathrm{~mm}$ long, $0.44-0.8 \mathrm{~mm}$ broad just at level of testes; anterior buccal sucker $62-80 \times 33-52 \mu$, pharynx $41-56 \times 31-44 \mu$; genital atrium $78-117 \mu$ in inside diameter, genital sucker at base of genital atrium shaped like flower-pot, $56-86 \times 46-65 \mu$, bearing a midventrally interrupted circle of $12-15$ rods about $20 \mu$ long; longer ventral atrial rod up to $65 \mu$ long, shorter dorsal atrial rod up to about $18 \mu$ in median field. Genital and vaginal pores $0.14-0.17 \mathrm{~mm}$ and $0.4-0.7 \mathrm{~mm}$ respectively from anterior extremity. Ovary $0.22-0.5 \times 0.18-0.3 \mathrm{~mm}$. No mature eggs observed.

\section{Microcotyle sebastisci n. sp.}

(Pl. IV, Fig. 13)

Habitat: Gills of Sebastiscus marmoratus, Sebastodes güntheri, Sebastichthys pachy. cephalus and Epinephelus akaara.

Material, locality and date: 20 mature specimens from Sebastiscus marmoratus (type host) from Inland Sea (April 30, 1957), 8 specimens from Epinephelus akaara from Inland Sea (September 9, 1957), 2 specimens from Sebastodes giuntheri from Inland Sea (March 15, 1958), and 11 specimens from Sebastichthys pachycephalus from Sagami Bay (June 5, 1958).

Described from mature specimens alone. Body flattened fusiform, 1.7-4.4 $\mathrm{mm}$ in length, with maximum breadth of $0.7-1.1 \mathrm{~mm}$ in midregion of body proper; cotylophore wedge-shaped, with 29-62 clamps in all ; 11-31 clamps on each side, equal or unequal in number, slightly diminishing in size posteriorly; largest clamp near anterior end of cotylophore, about $80 \mu$ in transverse diameter, with simple pointed accessory piece for posterior ramus of median piece like that of Microcotyle sebastis Goto, 1894. Anterior extremity forming a flat elevation beyond anterior suckers; latter $40-60 \times$ 50-80 $\mu$, with distinct partition at middle; pharynx globular, 40-78 $\times 40-80 \mu$. Esophagus with sinuous walls, sending off few lateral diverticles, bifurcating just behind genital pore. Ceca with irregular outer and inner branches, right one terminating at posterior end of body proper, left one extending some distance into cotylophore.

Testes 8-20 in number, occupying whole postovarian intercecal area. Vas deferens winding forward dorsal to uterus; its distal portion well differentiated and leading into conical cirrus, which projects into the funnel- or cup-shaped posterior recess of the genital atrium, the lateral wall of which is spined, though sparsely, like the genital atrium proper. The genital atrium surrounded by radiating muscle fibers is approximately reniform, with maximum inside diameter of $0.1-0.24 \mathrm{~mm}$, and covered inside with short spines except at the median anterodorsal area, whence a bulbous fibrous swelling well delimited from the surroundings projects forwards as preatrial bulb, but 
occasionally this bulb may be flattened or may project into the genital atrium. Genital pore transversely elongated oval, close to median posterior border of genital atrium proper.

Ovary $0.2-0.55 \times 0.2-0.6 \mathrm{~mm}$, in form of an interrogation mark, with the attenuated proximal portion turned back on itself in front of anteriormost testis, and the distal portion also folded upon itself and arched across the median field behind middle of body proper; germiduct winding, may be distended with sperm before giving off genito-intestinal duct, which passes toward the right cecum between the germiduct and the winding proximal portion of the ovary. The ootype lies on the left of the ascending portion of the ovary dorsal to the unpaired vitelline duct which joins the germiduct just distal to the origin of the genito-intestinal duct. Uterus median, ventral to vas deferens, opening into posterior recess of genital atrium ventral to cirrus; eggs $0.2-0.22 \mathrm{~mm}$ long by $0.09-0.1 \mathrm{~mm}$ wide, with a very long filament at anterior pole and a much shorter filament at posterior pole. Vitelline follicles surrounding ceca except for posterior end of left cecum extending into cotylophore. The paired vitelline ducts distended with yolk cells follow a short sinuous descending course, one on each side of the uterus and connected with each other by a transverse commissure anteriorly and by a $\mathrm{Y}$-shaped commissure posteriorly ventral to the arcuate distal portion of the ovary. Vagina transversely elongated oval, opening middorsally by a small aperture some distance back of intestinal bifurcation; it is connected with the transverse vitelline commissure by a median vaginal duct running dorsal to the vas deferens. Excretory vesicles tubular, paired, oblique, opening laterally at level of preatrial bulb by means of several minute pores.

This species most closely resembles Microcotyle tanago YamaGUTI, 1940, in the general shape of the body, but differs from it in the presence of a prominent conical cirrus projecting into the posterior chamber of the genital atrium, and from $M$. $d i$ trematis YAMAGUTI, 1940, in the shape and structure of the genital atrium, though similar in the structure of the cirrus. In M. caudata Goto, 1894, and M. sebastis Gото, 1894, from the related host species, the clamps are nearly alike in number, but the testes are somewhat more numerous (23 and 40 respectively according to GoTo). The eggs are $0.18 \mathrm{~mm}$ long by $60 \mu$ broad in caudata but much larger in the present species.

\section{Microcotyle tanago YAMAGUTI, 1940}

With addition of two mature specimens found in Ditrema temmincki BLEEKER from the Inland Sea this species is defined as follows; the original description of the species was based on a single mature specimen!

Body fusiform, $1.5-4.1 \mathrm{~mm}$ long by $0.36-0.8 \mathrm{~mm}$ broad. Cotylophore $0.75-1.3 \mathrm{~mm}$ long, clamps $50-90$ in total number, $38-85 \mu$ in diameter, without accessory piece for posterior ramus of median piece. Anterior extremity truncate. Anterior suckers with distinct partition, $30-60 \times 48-68 \mu$; pharynx $36-57 \times 36-60 \mu$, esophagus with a pair or 
two of side branches, bifurcating immediately behind genital pore. Ceca with inner and outer branches, left one extending some distance into cotylophore. Testes 11-24 in number, massed together in one layer in postovarian intercecal field. Vas deferens winding dorsal to uterus, forming a minute papilliform projection into the genital atrium. Genital atrium consisting of densely spined reniform anterior portion surmounted by an apparently solid bulbous swelling up to $0.11 \mathrm{~mm}$ in diameter and well delimited from the surroundings by lamellar fibers, paired lateral recesses surrounded by short radial muscles, and a bowl-shaped posterior median recess, into which open the vas deferens and uterus at the base. This median recess is up to $90 \mu$ in diameter, sparsely spined internally on each side, and opens to the outside anteroventrally immediately behind the densely spined reniform portion, with the somewhat depressed central area (about $40 \mu$ in diameter) of its dorsal wall covered with comparatively long hairs.

Ovary in form of interrogation mark, $0.18-0.8 \mathrm{~mm}$ anteroposteriorly, with its proximal end directly in front of anteriormost testes; germiduct winding, giving off genitointestinal duct just before uniting with vitelline duct. Ootype situated dorsolateral to descending unpaired vitelline duct; uterus running straight forward in ventral median field. Eggs fusiform, with long filament at each pole, about $80 \mu$ in diameter. Vitellaria surrounding ceca and their branches throughout except for their anterior end; paired vitelline ducts joining together ventral to anterior arch of ovary. Vagina oval to elliptical, $40-70 \mu$ long by $30-50 \mu$ broad, opening middorsally at its anterior end at a distance of $0.3-0.8 \mathrm{~mm}$ from anterior extremity.

\section{Prosomicrocotyla gotoi (Yamaguti, 1934) n. comb.}

Habitat: Gill of Hexagrammos otakii JorD. et ST.

Locality and date: Ise Bay; April 2, 1958.

25 mature of gravid specimens flattened under cover glass pressure, stained and mounted in toto showed the following variations.

Body $3.9-5.5 \mathrm{~mm}$ in length, $0.83-1.6 \mathrm{~mm}$ in width at level of ovary. Pedunculate clamps arranged in form of a frill around posterior half of body, varying in number on each side from 25 in youngest mature specimen $2.9 \mathrm{~mm}$ long to 52 in largest gravid specimen $5.5 \mathrm{~mm}$ long, commencing at level of ovary. Septate anterior sucker $54-75 \mu$ in longer transverse diameter and $36-54 \mu$ in shorter diameter, pharynx $59-87 \times 54-78 \mu$. Testes 40-90 in number, in postovarian median field, terminating short of posterior extremity, which is usually concave or more or less deeply notched. Genital atrium forming armed sucker-like structure $62-99 \mu$ long by $52-88 \mu$ wide, esophageal or bifurcal. Ovary vermiform, folded back on itself, measuring as a whole $0.4-1.0 \times 0.3-0.7 \mathrm{~mm}$. Uterus distended in fully gravid specimens in form of a spindle or a lemon; eggs $190-221 \mu$ long by $72-111 \mu$ wide; anterior polar filament very long and coiled, posterior shorter, with recurved tip. 
This species and P. chiri (GoTO, 1894) $)^{1}$ are characterized by the body being oval to spatulate, and the haptor being divided into two separate frills, each of which is attached to the posterior lateral margin of the body, commencing at the level of the ovary. In all the known members of Microcotyle the body is lanceolate, and the haptor is undivided, the two frills meeting posteriorly. For these reasons the former are separated from the latter as representing a separate genus, for which the name Prosomicrocotyla is suggested in reference to the anterior position of the haptor.

\section{Prosomicrocotyla n. g.}

Generic diagnosis.-Microcotylinae: Body spatulate. Haptor divided into two separate frills bordering posterior half of body proper, commencing at level of ovary and not meeting posteriorly; each frill bearing a row of numerous clamps of uniform structure. Terminal anchors absent. Esophagus simple or with lateral diverticula; intestinal crura with outer branches; inner branches, however, may be present or absent. Testes numerous. Cirrus not differentiated. Genital atrium forming a sucker-like structure armed with spines. Genital pore esophageal or just prebifurcal. Ovary convoluted, with distal end directed backward, median, pretesticular. Genito-intestinal duct crossing proximal portion of ovary. Egg filamented at each pole. Vagina single, with middorsal opening; vaginal duct inverted $\mathrm{Y}$-shaped. Vitellaria entirely or largely co-extensive with intestine and its branches. Parasitic on gills of marine teleosts.

Genotype: P. gotoi (YAMAGUTI, 1934), on Hexagrammos otakii; Ise Bay, Inland Sea, Japan.

Other species: P. chiri (GoTo, 1894), on Hexagrammos otakii; Hakodate, Japan.

\section{Axine (Axinoides) sebastisci n. sp.}

(Pl. III, Fig. 10)

Habitat: Gills of Sebastiscus marmoratus Cuv. et VALENC.

Material: Three mature specimens.

Locality and date: Inland Sea; September 14, 1957.

Body $2.25-2.5 \mathrm{~mm}$ long, $0.7-0.8 \mathrm{~mm}$ broad at posteror end of body proper, whence it tapers gradually toward the level of the anterior end of the vitellaria, then abruptly narrowed to a slender, blunt-pointed, anterior extremity, which has a median incision in front and a minute median papilla anterodorsally. Anterior sucker $20-30 \mu$ in diameter, without partition, though the anterior and posterior margins are elevated at the middle; pharynx $15-18 \times 13-15 \mu$. Esophagus $0.35-0.5 \mathrm{~mm}$ long, with sinuous walls, bifurcating just behind genital pore. Ceca with numerous, narrow, side branches, terminating at posterior extremity of body proper, which is slightly constricted off from the cotylophore provided with a row of 38-42 clamps. Each clamp skeleton consisting of an unpaired, U-shaped, median piece with bifid ends, two pairs of lateral and two pairs of apical, marginal pieces supporting the anterior and posterior valves, and a pair of shorter internal pieces, each of which is directed toward the end of the posterior arm of the median piece along the inner surface of the posterior valve, with its point projecting internally over the surface of the valve.

1) In this species the testes are about 25 in number. 
Testes rounded 14-30 in number, massed closely together in one layer and occupying whole postovarian intercecal area. Vas deferens winding forward ventral to ovary, then on the right of uterus and finally dorsal to latter; pars prostatica well differentiated, elliptical, $15 \mu$ in diameter in the type; prostatic cells massed together on each side of body from level of pars prostatica to that of genital pore; cirrus disc-shaped, $30-40 \mu$ in diameter, and provided at its central opening with numerous spines which are arranged in two or three circular rows.

The cirrus and uterus open into the genital atrium which in turn opens outside by a large, oval, midventral aperture ( $42 \mu$ in transverse diameter in the type) surrounded by circular muscle fibers at a distance of $0.4-0.5 \mathrm{~mm}$ from the anterior extremity.

Ovary turned back on itself posteriorly, with its anterior portion on the right of median line; the germiduct arising from the anterior end of the ovary turns mesad abruptly at the point where the genito-intestinal duct is given off, and after joining the common vitelline duct runs backward and then turns back on itself to lead into the ootype, the latter extends forward from the left side of the ovary to the level where the ascending genito-intestinal duct opens into the right cecum. Uterus running straight forward ventral to vas deferens. Vitellaria extending profusely along intestine and its branches from a short distance $(0.1 \mathrm{~mm}$ in the type) behind vagina to near cotylophore, anterior portion of intestine free of vitellaria ; paired vitelline ducts joining together a short distance $(0.12 \mathrm{~mm}$ in the type) behind anterior end of vitellaria, unpaired duct long, descending in median line ventral to uterus. Vagina funnel-shaped, covered inside with dentiform spines, opening middorsally at the level where the body tapers abruptly, $0.1-0.12 \mathrm{~mm}$ behind genital pore. Vaginal duct narrow, apparently continued backward toward junction of paired vitelline ducts, from which a narrow median duct can be traced forward for a short distance. In front of the vaginal pore is a shallow depression, from which projects dorsad a blunt-pointed spine $18 \mu$ long as in A. tylosuri Yamaguti, 1938.

\section{Polystomatoidea Price, 1936}

\section{Hexabothriidae PRICE, 1942}

\section{Squaloncocotyle laymani $\mathrm{n}$. $\mathrm{sp}$.}

(Pl. IV, Fig. 12)

Habitat: Gills of Mustelus manazo (BLEEKER).

Material: $\mathbf{5}$ gravid specimens.

Locality and date: Inland Sea; April 30, 1957.

Body very much elongated, tapered anteriorly, $8.5-14 \mathrm{~mm}$ long by $1.2-1.4 \mathrm{~mm}$ broad. Of the three pairs of haptoral suckers one opposite the appendix is somewhat smaller than the other two, $0.32-0.36 \mathrm{~mm}$ in diameter, and the sclerite measures 0.6 $0.62 \mathrm{~mm}$ inclusive of its apical hook, while the other suckers are $0.35-0.38 \mathrm{~mm}$ in 
diameter, with the sclerite and hook measuring $0.75-0.92 \mathrm{~mm}$ in combined length; haptoral appendix $0.8-1.1 \mathrm{~mm}$ long by $0.4-0.53 \mathrm{~mm}$ wide, its apical suckers barrelshaped, $0.12-0.14 \mathrm{~mm}$ in diameter, $0.21 \mathrm{~mm}$ in length including basal accessory sucker, which is well constricted off from the main sucker lined with thick strongly sclerotized cuticle; paired anchors situated near apex of haptoral appendix about 40-50 long, with V-shaped root.

Oral sucker subterminal, surmounted by prominent semicircular hood $0.31-0.39 \mathrm{~mm}$ in transverse diameter, followed by short prepharynx; pharynx oval, $70-110 \mu$ in diameter. No esophagus. Ceca with short inner and longer outer branches, united at posterior end of body proper, common cecum sending a long simple branch into haptoral appendix and another short one toward the opposite direction.

Testes rounded, very numerous (100 or more), arranged close together in one layer in postovarian intercecal field. Vas deferens strongly winding in median field dorsal to uterus, its distal portion is provided with circular muscles for a distance of $0.12-0.25 \mathrm{~mm}$; pars prostatica $0.1-0.15 \mathrm{~mm}$ long, well marked off from distal muscular portion of vas deferens, somewhat enlarged anteriorly in form of a narrow funnel; prostatic cells grouped around vas deferens and uterus far back of pars prostatica. Cirrus forming a large oval bulb $0.13-0.15 \mathrm{~mm}$ long by $0.12-0.15 \mathrm{~mm}$ wide and composed of meridional muscle fibers, opening at center of genital atrium almost entirely occupied by bulbus cirri, with a large circular aperture, whose margin is fringed with very minute pointed filaments.

Ovary $0.85-1.4 \mathrm{~mm}$ long by $0.4-0.5 \mathrm{~mm}$ wide, irregularly multilobed, or rather branched at some places, turned back on itself near its distal end, which lies about the middle of the body proper. The anterior end of the ovary extends further forward than the vitelline reservoir. The narrow winding germiduct first joins the seminal receptacle which is elongated elliptical, $0.25-0.42 \mathrm{~mm}$ long by $0.05-0.12 \mathrm{~mm}$ wide, and lies obliquely just in front of the distal end of the ovary, and then the ductus genito-intestinalis opening into the right cecum; close to this junction the germiduct receives the duct from the vitelline reservoir, and finally turning back on itself leads into the ootype. At this point is a sphincter-like thickening. Ootype very strongly developed, elliptical to fusiform, surrounded by shell gland ducts, shell gland cells lying well apart from ootype. Uterus ventromedian, opening into genital atrium ventral to bulbus cirri ; eggs fusiform, about $0.2 \mathrm{~mm}$ long, with a comparatively short filament $(0.1-0.15 \mathrm{~mm})$ at each pole, total length about $0.45 \mathrm{~mm}$. Vitellaria extending along ceca from a short distance behind genital pore to near posterior end of body proper, leaving posterior end of paired ceca free or not. Vitelline reservoir $\mathrm{Y}$ - or T-shaped, dorsal to ovary. Vagina double, each opening ventrally near lateral margin of body at level of bulbus cirri, with villous lining at its comparatively wide distal portion, narrowed as it proceeds obliquely inwards and backwards; vaginal ducts very narrow, without above mentioned lining, parallel to each other, each opening into arm of vitelline reservoir on its own side.

The present species, apparently identical with Squaloncocotyle sp. of LAymaN 
(1931) from the same host species of the Sea of Japan, very closely resembles Squaloncocotyle somniosi (CAUSEY, 1926) from the Pacific coast of America, but in the latter species the egg has a single short filament. In S. sphyrnae MacCallum, 1931, the hook of the haptoral sclerite is comparatively long. In S. catenulata GUBERLET, 1933, from a related host, the ovary extends forward beyond the arms of the vitelline reservoir just as in the present species, but the germiduct is stated to be convoluted before leading into the ootype, and the egg has a very long filament at one pole but none at the other pole.

\section{Acknowledgements}

I wish to express my gratitude to the Enoshima Aquarium at Katase, Kanagawa Prefecture, the Seto Marine Biological Laboratory of Kyoto University, the Tamano Marine Laboratory of Okayama University, and the Oceanographical Museum of Tamano City, Okayama Prefecture, for their generous supply of the fish materials, from which the parasites described here were collected.

\section{LITERATURE}

Beneden, P. J. van, and Hesse, C. E. 1863. Recherches sur les bdellodes ou hirudinés et les trématodes marines. Mém. Acad. R. Belg., 34, 1-142.

Caballero y, C. E., Bravo H. M. and Grocott, R. G. 1954. Helmintos de la República de Panama. XII. Descripción de dos nuevos trématodos monogéneos, parasitos de peces marinos comestibles del Océano Pacifico del Norte. Ciencia, México, 14 (4-6), 81-86.

CAUSEY, D. 1926. Onchocotyle somniosi n. sp., an ectoparastitic trematode of the sleeper shark (Somniosus microcephalus). Parasit., 18, 195-202.

Cerfontaine, P. 1895. Le genre Anthocotyle. Bull. Acad. Belg. Cl. Sc., 29, 510-527.

Goto, S. 1894. Studies on the ectoparasitic trematodes of Japan. J. Coll. Sc. Tokyo, 8, 1-273.

Guberlet, J. E. 1933. Notes on some Onchocotylidae from Naples, with a description of a new species. Pubbl. Staz. Napoli, 12, 323-336.

Layman, E. M. 1930. Parasitic worms from the fishes of Peter the Great Bay. Bull. Pacif. Sci. Fish. Res. Stat., Vladivostok, 3, 1-120.

MacCallum, G. A. 1931. Four new species of trematode worms of the subfamily Onchocotylinae. Proc. U. S. Nat. Mus., 79, 1-8.

Mizelle, J. D. and Blatz, V. 1941. Studies on monogenetic trematodes, VI. Two new dactylogyrid genera from Florida fishes. Ȧmer. Midl. Nat., 26, 105-109.

Murray, F. V. (1931) Gill trematodes from some Australian fishes. Parasit., 23, 492-506.

Price, E. W. 1937. North American monogenetic trematodes. I. The superfamily Gyrodactyloidea. J. Wash. Acad. Sc., 27, 114-130.

1937. Redescription of the two exotic species of monogenetic trematodes of the family Capsalidae Baird from the MacCallum Collection. Proc. Helm. Soc. Wash., 4, 25-27.

Sproston, N. G. 1946. A synopsis of the monogenetic trematodes. Tr. Zool. Soc. London 25 (4), $185-600$.

YamaguTI, S. 1934. Studies on the helminth fauna of Japan. Pt. 2. Trematodes of fishes, I. Jap. J. Zool., 5 (3), 249-541.

1938. Studies on the helminth fauna of Japan. Pt. 24. Trematodes of fishes, V.

Ibid., 8 (1), 15-74.

1040. Studies on the helminth fauna of Japan. Pt. 31. Trematodes of fishes, VII.

Ibid., 9 (1), 35-108. 


\section{EXPLANATION OF PLATES III-IV}

\section{Plate III}

Fig. 1. Udonella caligorum JoHNSTON, 1835, ventral view.

Fig. 2. Megaloncus arelisci n. g., n. sp., body proper in ventral view, opisthohaptor in dorsolateral view.

Fig. 3. Anchor complex of opisthohaptor of Megaloncus arelisci, lateral view.

1) Principal claw. 2) Basal piece. 3) Saddle of principal claw.

4) Bar. 5) Saddle of bar. 6) Accessory piece of bar.

Fig. 4. Benedeniella congeri n. g., n. sp., ventral view.

Fig. 5. Metabenedeniella hoplognathi n. g., n. sp., ventral view.

Fig. 6. Pseudamphibdella paralichthydis n. g., n. sp., ventral view.

Fig. 7. Pseudomicrobothrium spari n. g., n. sp., ventral view.

Fig. 8. Osphyobothrus parapercis n. g., n. sp., ventral view.

Fig. 9. Skeleton of clamp of Osphyobothrus parapercis.

Fig. 10. Axine (Axinoides) sebastisci n. sp., ventral view.

\section{Plate IV}

Fig. 11. Microncotrema lateolabracis n. g., n. sp., ventral view.

Fig. 12. Squaloncocotyle laymani $\mathrm{n}$. sp., dorsal view.

Fig. 13. Microcotyle sebastisci n. sp., ventral view.

Fig. 14. Murraytrematoides ditrematis n. g., n. sp., ventral view.

Fig. 15. Microcotyle gimpo n. sp., ventral view.

Fig. 16. Geneticoenteron lateolabracis n. g., n. sp., ventral view.

Fig. 17. Pseudomurraytrema spari n. g., n. sp., ventral view.

Fig. 18. Pseudorhabdosynochus epinepheli n. g., n. sp., dorsal view. 
Publ. Seto Mar. Biol. Lab., VII, 1 (1958)
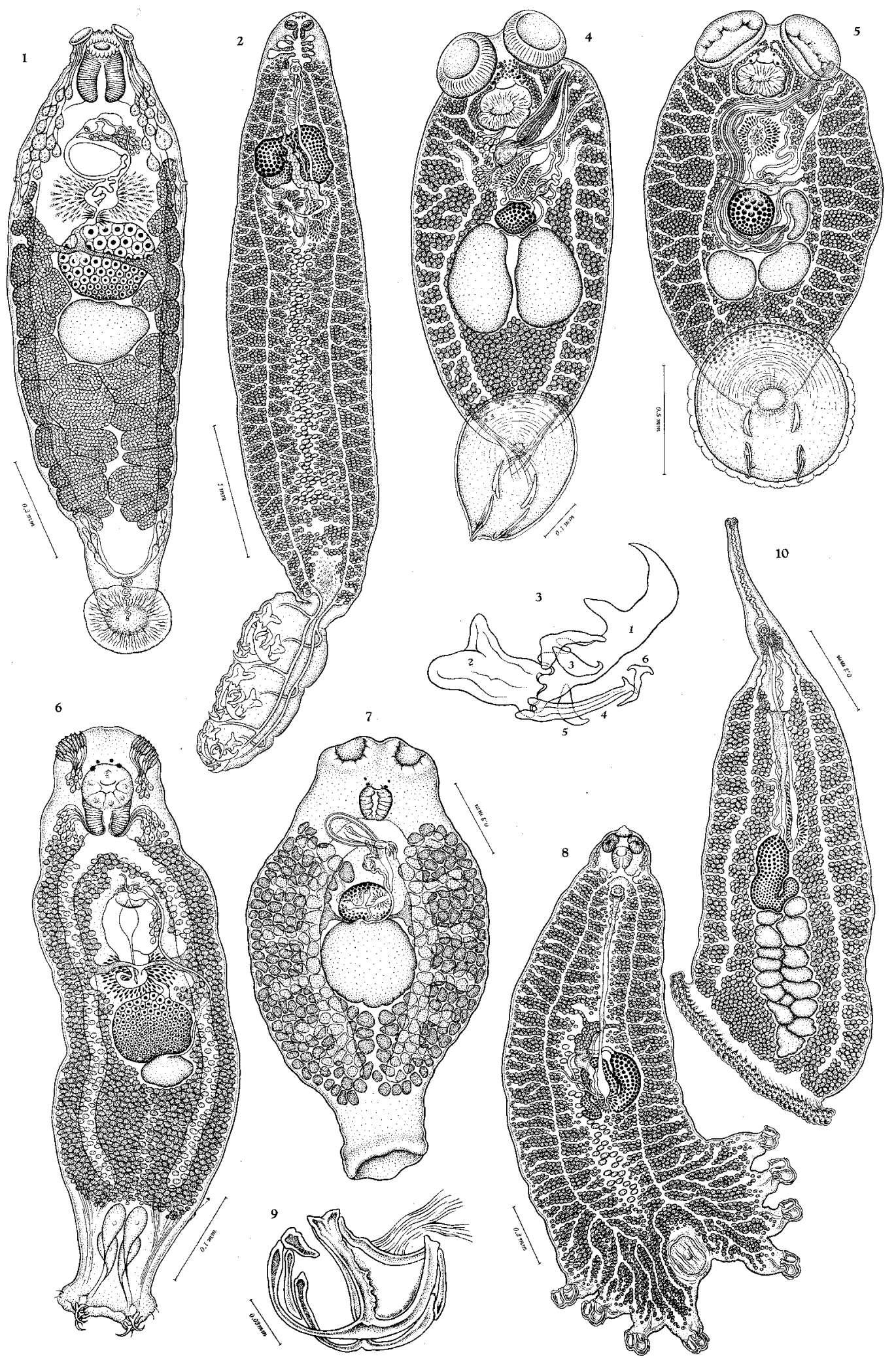

S. Yamaguti: Studies on the Helminth Fauna of Japan, 53. 

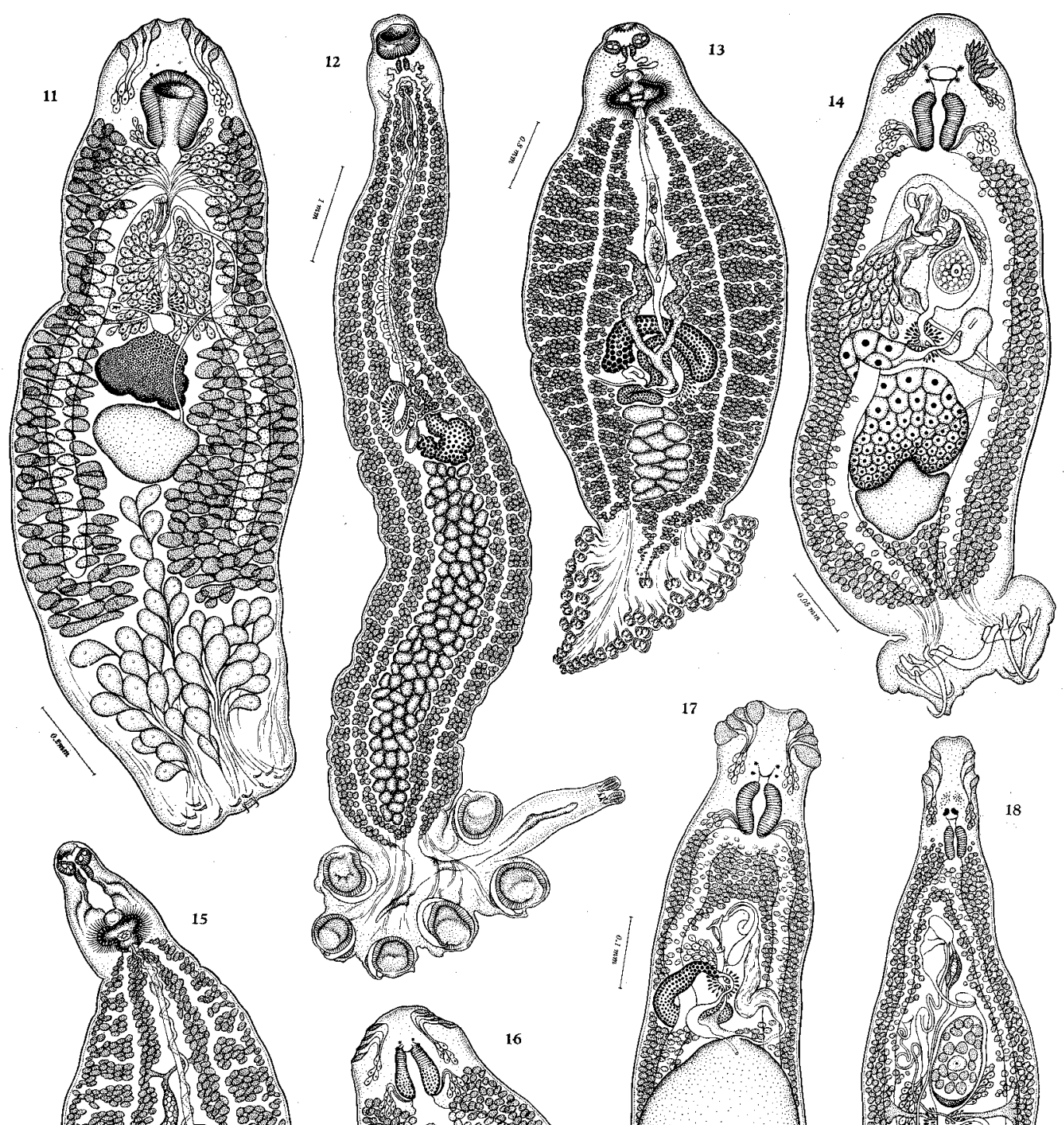
\% 1. 3. 3 \% 6. 2. (1)

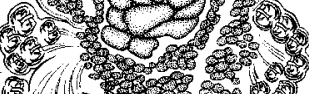
(5) ( (1) (63) (10)

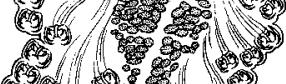
(10) (1) 2.
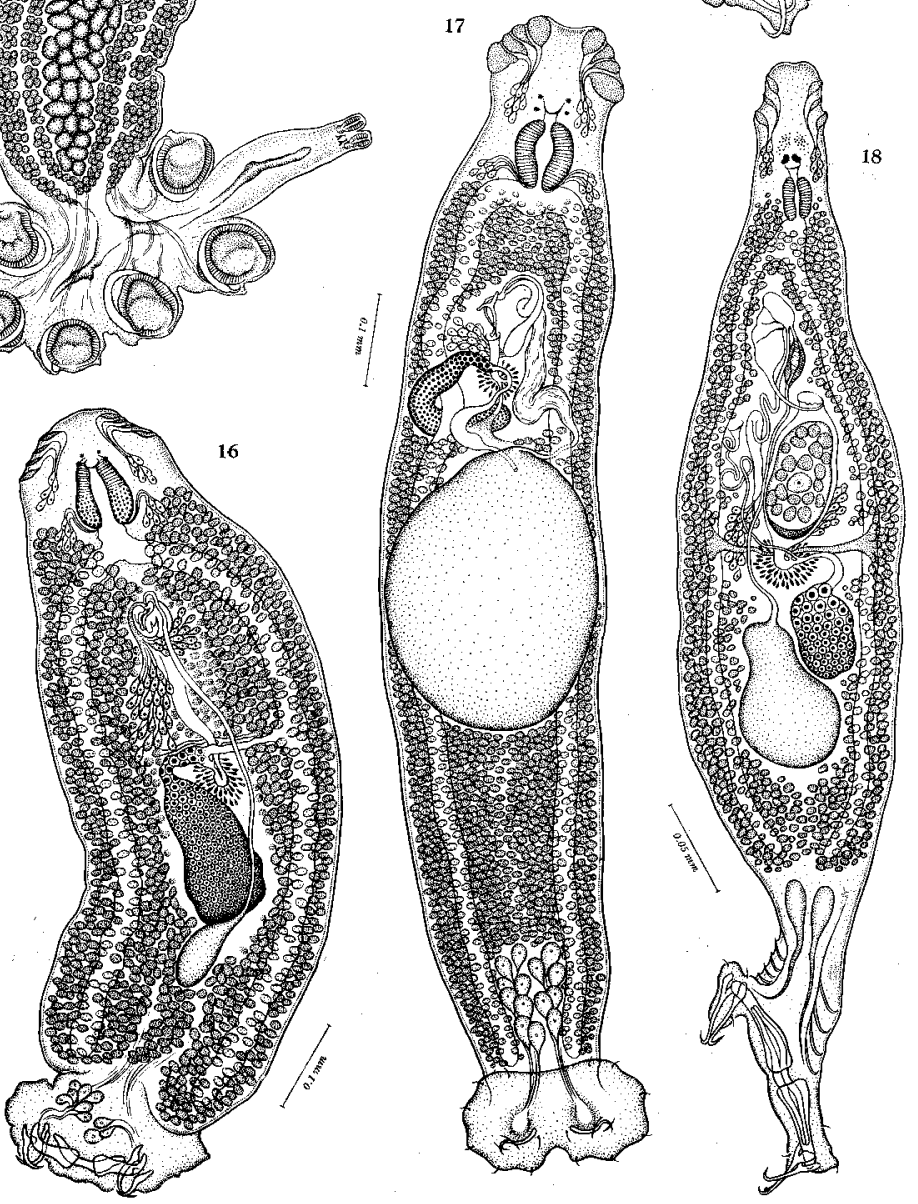